\title{
GROUNDWATER POTENTIAL ZONE DELINEATION IN HARD ROCK TERRAIN FOR SUSTAINABLE GROUNDWATER DEVELOPMENT AND MANAGEMENT IN SOUTH MADHYA PRADESH, INDIA
}

\author{
C. S. Dwivedi i" ${ }^{*}$, Raghib Raza', D. Mitra ${ }^{2}$, A.C. Pandey ${ }^{1}$, D. C. Jhariya ${ }^{3}$ \\ 'Department of Geoinformatics, Central University of Jharkhand, Ranchi-835205, India \\ ${ }^{2}$ Marine and Atmospheric Sciences Department, Indian Institute of Remote Sensing, ISRO Department of Space, \\ Govt. of India, Dehradun, India \\ ${ }^{3}$ Department of Applied Geology, National Institute of Technology, Raipur, GE Road, Raipur-492010, Chhattisgarh, \\ India. \\ *Corresponding author: chandra.dwivedi@cuj.ac.in \\ Received: November 1h, 2020 / Accepted: February 16 ${ }^{\text {th }}, 2021$ / Published: April $1^{\text {st }}, 2021$ \\ https://DOI-10.24057/2071-9388-2020-195
}

\begin{abstract}
In view of the vital significance of water resources and issues emerging from their temporal and spatial distribution and utilization posing serious problems to the land resources and to the society United Nations has identified sustainable management of water resources (SDG 6) as one of the seventeen major Sustainable Development Goals (SDGs). In this perspective, the purpose of the study is to identify the groundwater potential zones in the hard rock terrain of BetulChhindwara Region, Madhya Pradesh, India, using AHP technique. The study area comprises the sub-watersheds of Tawa river (Narmada basin), Tapi river (Tapi basin), Kanhan and Pench rivers (Godavari basin). Various thematic layers such as geomorphology, geology, physiography, rainfall, soil, slope, lineament, drainage density, groundwater depth, and land use/ land cover were developed. The analytical hierarchy process helps to delineate groundwater prospect zones, which are categorized into five classes, i.e. very poor, poor, moderate, good, and very good based on objective, criteria, and preference. The good, moderate, and poor groundwater potential zones cover 4815 sq. km., 6423 sq. km, and 4857 sq. km, respectively, comprising $22.46 \%, 29.96 \%$, and $22.65 \%$ of the entire region under study. The result indicates that $15.22 \%$ of the area comprising 3262.10 sq. km have very good groundwater potential whereas $9.71 \%$ (2080 sq. km) has very poor groundwater potential. The obtained result has been verified through field check based on the yield data collected from 16 bore wells in the study area. The accuracy of the results was $75 \%$ that proves the efficiency of the adopted techniques. Thus, this study will be efficient for the sustainable development and management of groundwater in the study area.
\end{abstract}

KEY WORDS: SDGs, Groundwater Potential Zones, Geographical Information System, Analytic Hierarchy Process, Betul-Chhindwara region

CITATION: C. S. Dwivedi, Raghib Raza, D. Mitra, A.C. Pandey, D. C. Jhariya (2021). Groundwater Potential Zone Delineation in Hard Rock Terrain for Sustainable Groundwater Development and Management in South Madhya Pradesh, India. Geography, Environment, Sustainability, Vol.14, No 1, p. 106-121 https://DOl-10.24057/2071-9388-2020-195

ACKNOWLEDGEMENTS: We express our sincere gratitude to NASA GES/DISC for providing satellite-based rainfall product LPDAAC for S2 satellite images and ASTER DEM products, Bhukosh, GSI for providing Geology and Geomorphology maps, NBSS-LUP for providing Soil map. We also thank CGWB, Bhopal, for providing information on groundwater level depth.

Conflict of interests: The authors reported no potential conflict of interest.

\section{INTRODUCTION}

The concept of sustainable development connotes the utilization and management of resources to meet the needs of humanity at present without compromising the potentiality for the future generation. As such, sustainable development planning entails inventory, evaluation, and physical planning of development. Resource inventory, entailing survey, mapping, and assessment of quantity and quality of resources, is a prerequisite for sustainable development planning. Water resources occupy a unique place in the array of natural resources. Their temporal and spatial distribution and utilization also have posed serious problems to the land resources and the society. These problems include land degradation, salinization, waterlogging and lowering of the water table, and depletion of groundwater resources. Because of the vital significance of water resources, one of the seventeen Sustainable Development Goals (SDGs) of the United Nations is to ensure availability and sustainable management of water and sanitation.

Sustainable development of water resources is impossible until we study the fast deteriorating groundwater potential and address the issue practically and scientifically. Groundwater is vital resource and significant factor in meeting the water prerequisites of different segments, including their real users in agricultural, industrial, and domestic sectors. The manageable improvement 
of groundwater requires exact quantitative evaluation depending upon technically legal standards. The escalated use of groundwater in some areas of India has caused a rapid decrease in groundwater level. The estimated groundwater potential in India is 399 billion cubic meters (MOWR 2009). Therefore, significant steps for the tapping of potential groundwater sites need to be assessed at the utmost to fulfill the ever increasing demands of freshwater.

The groundwater availability and movement depend on different factors such as the density of lineament, Land Use Land Cover (LULC), geomorphology, geology, soil type, drainage density, slope etc. (Jaiswal et al. 2003; Shankar and Mohan 2005; Dwivedi 2007; Shekhar et al. 2014; Tirkey et al. 2016). Several researchers globally used geospatial technique to map groundwater prospect zone by incorporating the above mentioned layers of hard rock terrains (Gupta and Srivastava 2010; Jha et al. 2010; Mukherjee P. et al 2012; Fashae et al. 2014; Tirkey et al. 2016; Das 2017; Dwivedi et al. 2017). The emerging geospatial techniques are an inevitable and reliable tool in hydrogeological studies, especially for modelling and monitoring groundwater resources (Krishnamurthy et al. 1996; Chowdhury et al. 2009; Machiwal et al. 2011).

Groundwater prospect zones delineation through appropriate analytic methods becomes essential to manage, monitor, and balance the use of groundwater resources. The multi-criteria decision-making technique (MCDM) supports the proper sustainable management of groundwater resources of the region. MCDM involves many complex criteria for handling the problem and gives a realistic solution based on field investigation, pilot studies, and experienced consultancies (Dunning et al. 2000; Flug et al. 2000; Joubert et al. 2003). There are numerous MCDM techniques such as Analytical Hierarchy Process (AHP), Fuzzy AHP, and Multiple Attribute Utility Theory (MAUT). Among them AHP technique developed by Saaty (1980) is more reliable to manage the real-world problem and the natural resource-related problems such as structuring, prioritizing, distributing, and selecting resources, , and thematic ranking. (Saaty 1980; Malczewski 2006; Malczewski and Rinner 2015).

Numerous investigators have successfully applied the concept of Saaty's Analytical Hierarchy Process in GIS techniques for evaluating the probable zones of groundwater resources in various regions (Jha et al. 2010; Machiwal et al. 2011; Shekhar and
Pandey 2015; Machiwal et al. 2015; Jhariya et al. 2016; Chowdhury et al. 2009). They found that the GIS technique and AHP are advantageous to plan sustainable utilization of groundwater resources in hard rock areas.

Groundwater is a vital component of the environment being a major source of supply throughout the world. Groundwater occurrence depends on geology, topography, drainage, land use, land cover, lineament, etc. We revealed rapidly increasing reliance on groundwater to meet the increasing water demands. This leads to water exhaustion and groundwater overconsumption causing ecological problems such as decreased water levels and water pollution. Therefore, there is a strong need to investigate groundwater occurrence using advanced techniques for sustainable development and management of this precious resource.

The Betul-Chhindwara region of Madhya Pradesh, India, faces water-related issues such as water scarcity, intermittent droughts, and groundwater depletion. The study area witnessed drinking water shortage and water deficiency during summer. The crop yield reduction observed in the study area is due to water shortage (Galkate et. al. 2008). The major part of the study area covering hard rocks gives less scope for groundwater occurrence due to poor aquifer conditions and high runoff. These precondition impose droughts therefore groundwater potential sites in the region need to be delineated using advanced techniques for sustainable development and management.

This study aims to investigate groundwater potential zones in the Betul-Chhindwara region using the AHP-based geospatial techniques for proper development and management of groundwater resources.

\section{STUDY REGION}

The Betul-Chhindwara region is positioned in the southern part of Madhya Pradesh, India, between $21^{\circ} 28^{\prime} \mathrm{N}$ and $21^{\circ} 54^{\prime}$ 40.3092" N latitudes and between $77^{\circ} 54^{\prime} 14.2308^{\prime \prime} \mathrm{E}$ and $79^{\circ} 24^{\prime} \mathrm{E}$ longitudes covering an area of $21440.8 \mathrm{~km} 2$. The location map of the study area is given in Figure 1.

The Betul-Chhindwara region is a part of the Middle Satpura Region. Geologically the whole area is covered by hard-rock

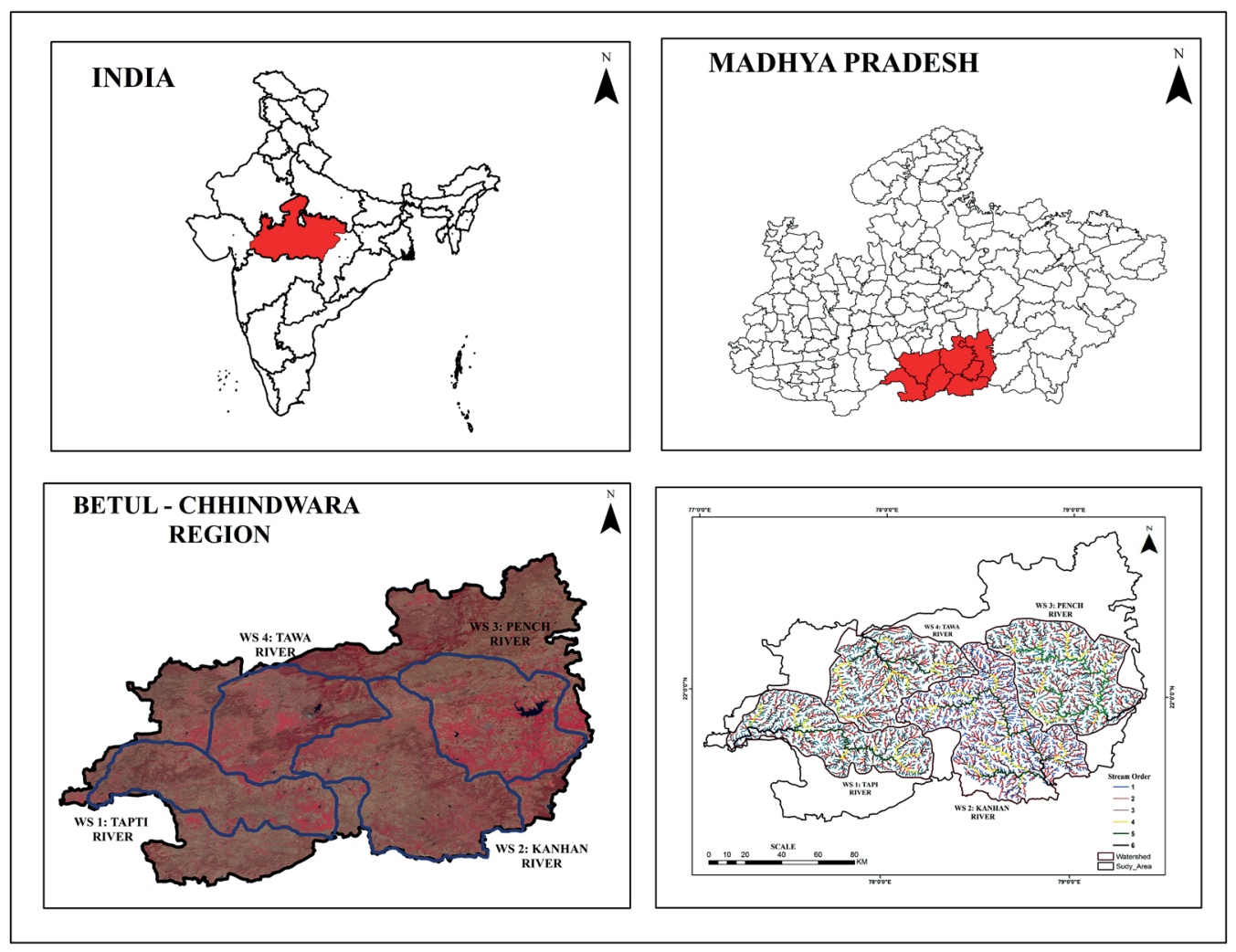

Fig. 1. Study area location with delineated watersheds 
formations (CGWB 2009). This area is drained by seasonal rivers such as Pench, Tawa, Kanhan, and Tapi. Topographically entire region is undulating and dissected; many elongated hillocks are elevated to an altitude of from300 meters to 900 meters above MSL (Dehriya, 2014). The climate of the region is tropical with three main periods such as winter, summer, and monsoon. In May the temperature rises to $44^{\circ} \mathrm{C}$ while January is considered the coldest month, in which the temperature lowers up to $12^{\circ} \mathrm{C}$. The study region receives maximum rainfall in July. The reported average annual rainfall of the region is $1,130 \mathrm{~mm}$ while spatial distribution is very uneven. The annual rainfall in most of the area (approx. $89 \%$ of total area) is less than $850 \mathrm{~mm}$, which is a scanty amount.

\section{MATERIALS AND METHODS}

To delineate groundwater prospect zone in the study using ten thematic layers such as geomorphology, geology, rainfall, physiography, soil, slope, lineament, drainage density, land use/land cover, and groundwater depth we used the multi-criteria decision method based on the Analytical Hierarchy Process (AHP).

The comprehensive flowchart representing the adopted methodology is illustrated in Figure 2.
Sentinel-2 satellite data was downloaded from the USGS website and thereby rectified and geo-referenced to prepare LULC and the investigated area's lineament map using ERDAS 9.3 ArcGIS 10.4 software. LULC map was generated using supervised classification with maximum likelihood classifier in ERDAS Imagine 9.3. The drainage map was digitized from the Survey of India's toposheet and rationalized with Sentinel-2 imagery for mapping recent stream networks. ASTER DEM data was used to develop a slope map of the area. The geology and geomorphology map of the investigated area was made using published data procured from GSI. The soil map was prepared from the existing data sets of the National Bureau of Soil Survey and Land-Use Planning (NBSS and LUP). Groundwater level data for 2018 were provided by the Central Groundwater Board and were subsequently imported in the GIS environment and spatially interpolated to prepare the groundwater level map of the study area. Rainfall data for 2018 collected from the Tropical Rainfall Measuring Mission (TRMM), NASA, were sorted with the purpose of development of rainfall map.

All thematic layers were selected for evaluation and assignment of weights with the help of Saaty's AHP keeping in view the comparative significance of each segment in the occurrence of groundwater.

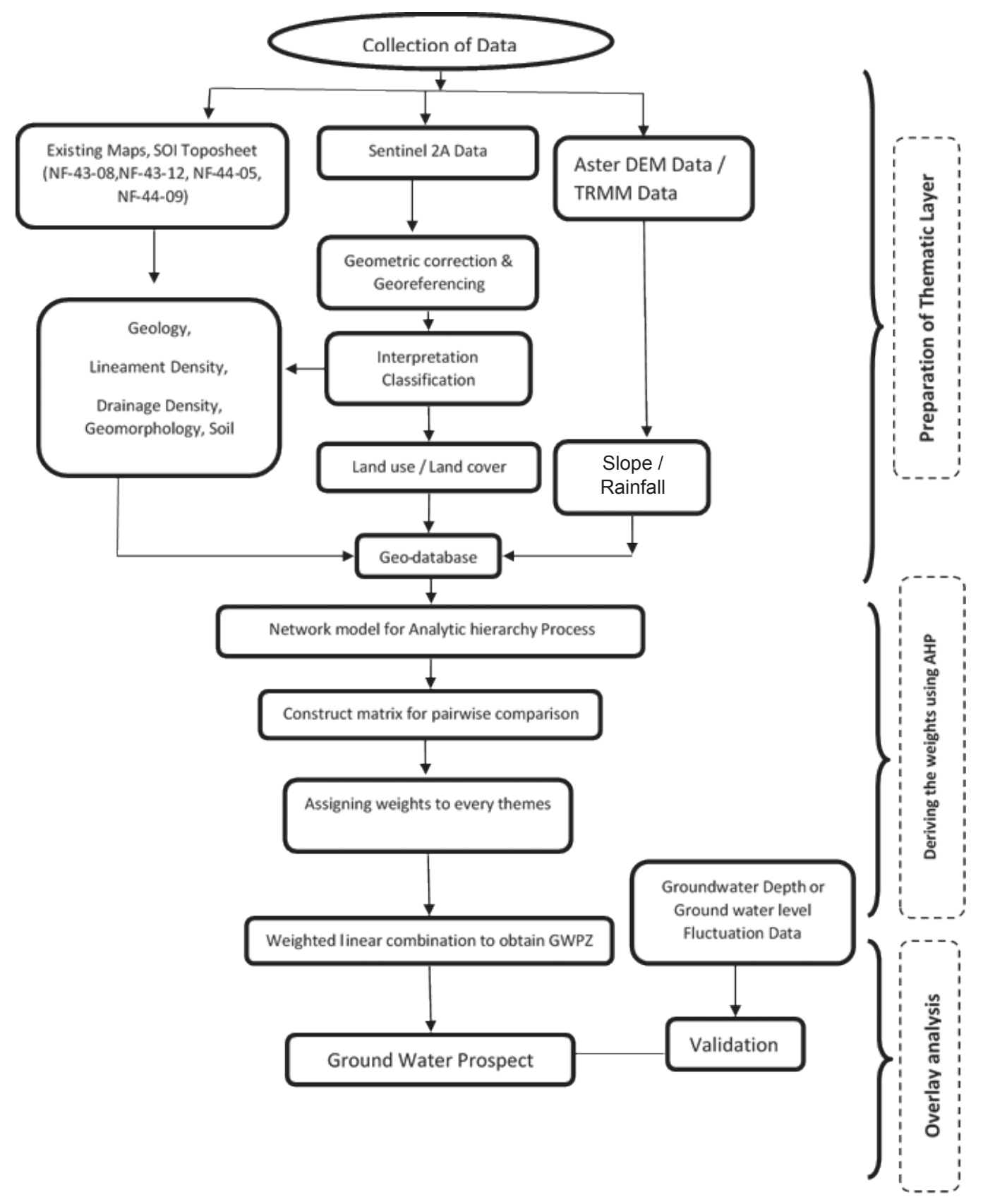

Fig. 2. Study area location with delineated watersheds 


\section{Thematic Layers Development Geomorphology}

Geomorphology of the region provides evidence of structural evolution and geomorphic process in the geological past (King 1962). The spatial occurrence and movement of groundwater depend on geomorphological features and its genesis (Dwivedi,2007). Based on landforms origin, the area under investigation was classified into seven distinct geomorphological units viz. pediment and pediplain complex, vertically dissected plateau, dissected hills and valleys, alluvial plain, dam, and reservoir (Fig. 3).

Pediment-Pediplain Complex unit is of denudational origin. It covers the major part of the study region occupying approximately $9542.65 \mathrm{sq}$. km (43.58\% of the area). Pediment has an erosional and undulating surface at the foot of hills while pediplain is an extended part of pediment with slopes varying from moderate to gentle (below 10 degrees) and formed by deep weathering and stream erosion. Pedimentpediplain complex unit are dispersed over the large area of Chhindwara, Betul, and Morabd plateau. Its groundwater potential varies from moderate to good. It is based on the underlying geological structure, lineament density, and weathering conditions of the region.

The dissected plateau is flat-topped, uneven with eroded structures, which are represented in the study region in a large quantity. We classified them into three classes: highly dissected, moderately dissected, and low dissected plateau. The second-largest geomorphological unit of the region is a moderately dissected plateau, which covers an area of 7742.83 sq. km. (35.36\% of the area). It is spread over the basaltic terrain of the region and has medium groundwater prospect due to vesicular, fracture porosity, and moderate runoff.

A highly dissected plateau is steep-sloped structures, which occupy approximately 9.6\% of the area (2121.95 sq. $\mathrm{km}$ ) of the region. It indicates poor groundwater prospects due to high runoff while steep escarpments with high relief features are recognized as dissected hills and valleys formed due to an intense erosional process and reflects that the region has low groundwater prospects.
All these landforms, on the basis of their origin can be classified under two broad categories viz. denudational and structural landforms. Denudational landform includes pediment, pediplain, dissected plateau etc. extended over upper and lower Gondwana sandstones. Groundwater potential of gneiss/granite rocks varies from moderate to good due to primary and secondary porosity (CGWB 2013). While structural landforms comprise dissected hills, valleys, escarpment, etc. capped with the Deccan trap with a thickness varying from $7 \mathrm{~m}$ to $21 \mathrm{~m}$ (CGWB 2013) they have a low groundwater potential due to steep slopes. Weightage was assigned as per the groundwater occurrence response of different geomorphic units of the study area.

\section{Rainfall}

Rainfall is considered an essential factor in hydrological studies. The groundwater level is directly dependent on the received rainfall amount in a particular area; therefore, spatial variability of rainfall often affects the aquifer's recharging rate (Guhathakurta and Rajeevan 2007).

High rainfall zone is characterized by a high weight whle low rainfall zones are characterized by a low weight. The study region receives maximum rainfall from the southwest monsoon - $1130 \mathrm{~mm}$ annually. However, the study area is characterized by a high spatial variability as Amarwada and Chhindwara plateaus are receiving a large amount of rainfall (above $950 \mathrm{~mm}$ ) while Betul plateau and Gwaligarh hills receive very small amount of rainfall (less than $600 \mathrm{~mm}$ ). The rainfall of the region was categorized into nine classes (Fig. 4).

\section{Geology}

The study area consists of Archaens and recent geological formation (CGWB 2009). The main geological units are metamorphic crystalline complex, Gondwana Supergroup, and Deccan Trap.

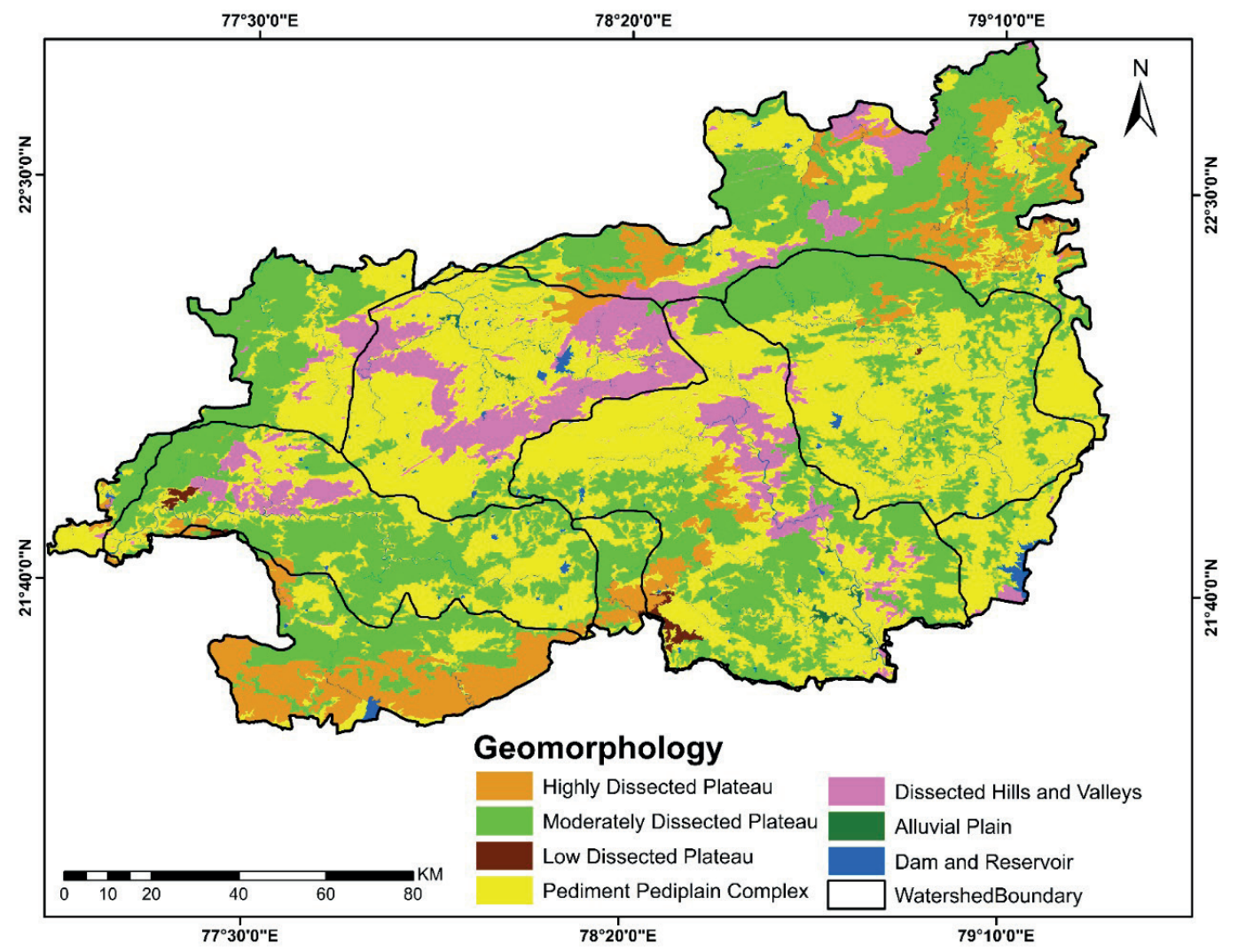

Fig. 3. Geomorphological setting of the selected study area 


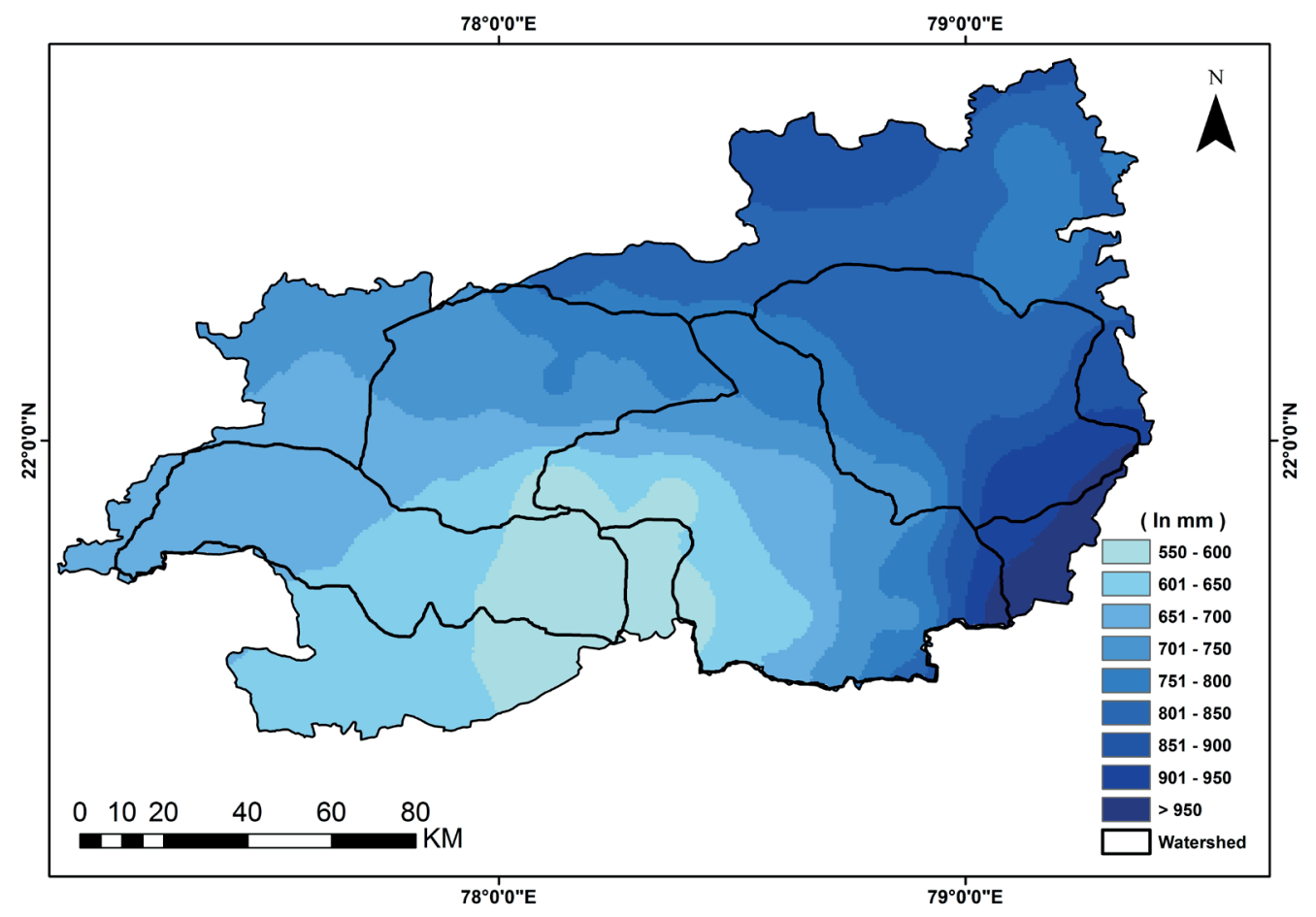

Fig. 4. Rainfall pattern in the selected study area

Low grade metamorphosed crystalline rocks are the basement rocks, including Sausar Series, granite, and gneiss rocks (Rajeeva et al. 2012). They are well exposed in the Sausar plateau and along the valley of the Kanhan river. Conditions in the lower and upper Gondwana sandstones are favourable for groundwater storage, which overlies the basement rock and Gondwana rock overlain by the Deccan trap (Murkute and Joshi 2015). The Deccan Trap covers the maximum portion of the study area, approximately 65\% (14309 sq. km.) of the whole region (Fig. 5). It is observed that lower and upper Gondwana rocks have high groundwater potential due to their intergranular porosity, while the granitic, basaltic, and gneissic rocks are characterized by a lower porosity due to their impermeable nature. In hard rock terrain, groundwater is mainly found in secondary porosity structures like fractures, joints, cleavage, and weathered surfaces. Therefore, these parameters have been assigned with corresponding weightage values due to their greater inclination to determine the groundwater potential.

\section{Physiographic division}

The study area is categorized into eight dominant physiographic units (Fig. 6). The Betul and Chhindwara plateaus are characterized by good groundwater conditions, followed by the Amarwara plateau.

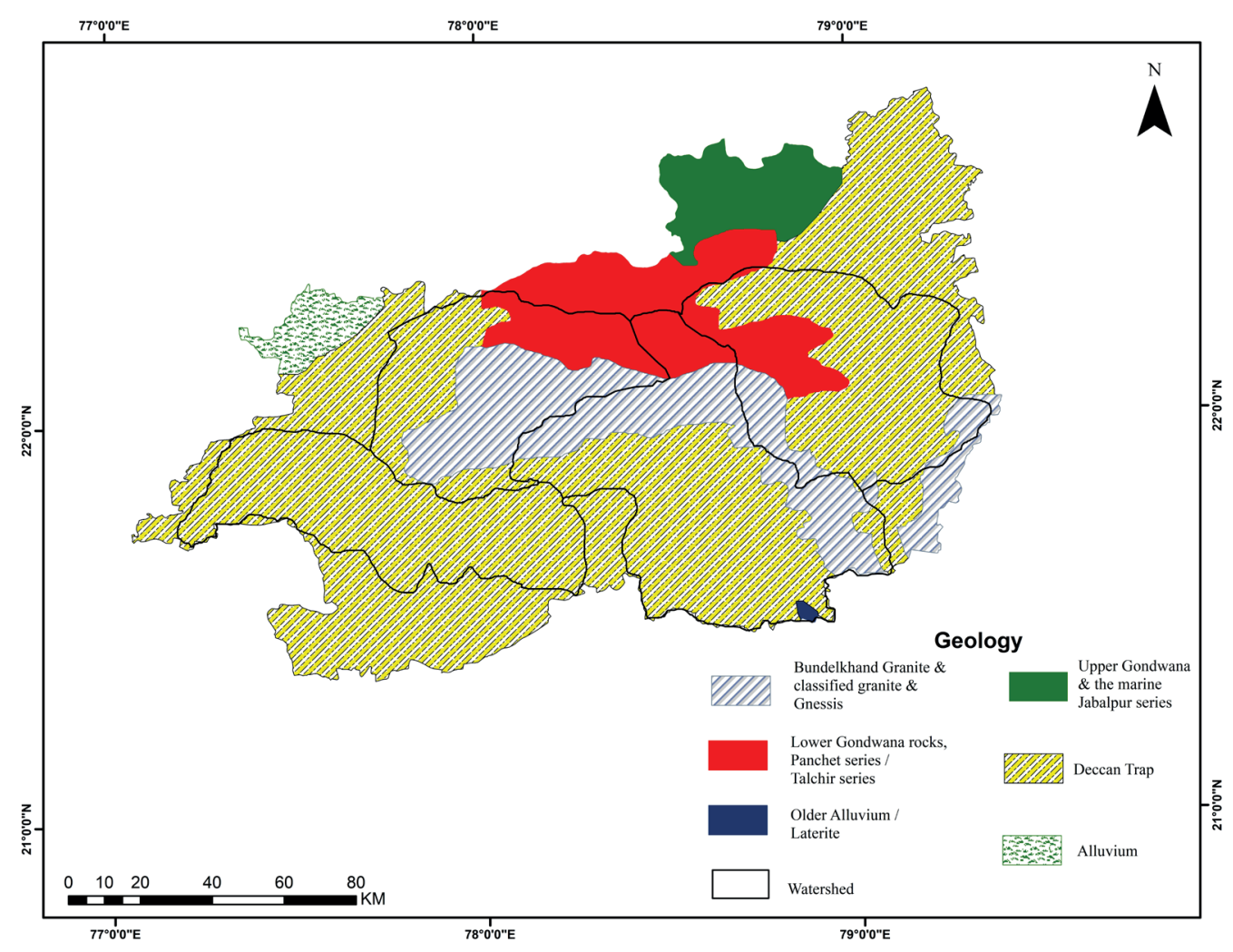

Fig. 5. Geology map of the selected study area 


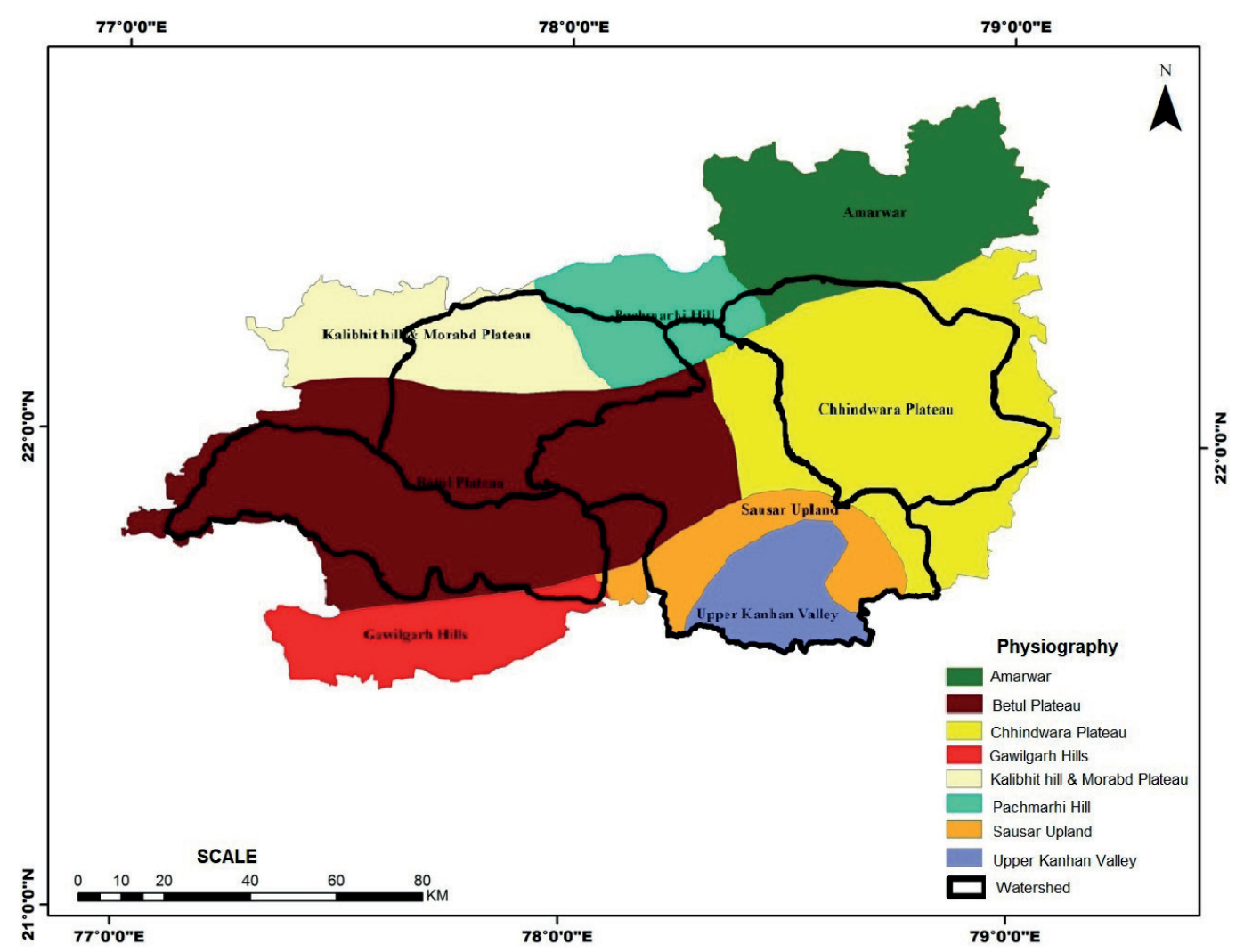

Fig. 6. Physiographic map of the selected study are

The Upper Kanhan valley has a moderate groundwater occurrence whereas Sausar upland and hills have a poor groundwater condition; the weightage values to these features was assigned accordingly.

\section{Soil}

Four dominant soil textures - sandy, silt, clay, and loamy - are observed in the study region (Fig. 7).
The soil rich in sand is usually characterized by a comparatively high rate of infiltration. Therefore, it is given higher priority; on the other hand, the soil with high clay material is characterized by a minimum infiltration rate; hence, its priority is the least. Weightage to soil layers was assigned as per their infiltration rate and transmission capacity, which allows for groundwater recharge.

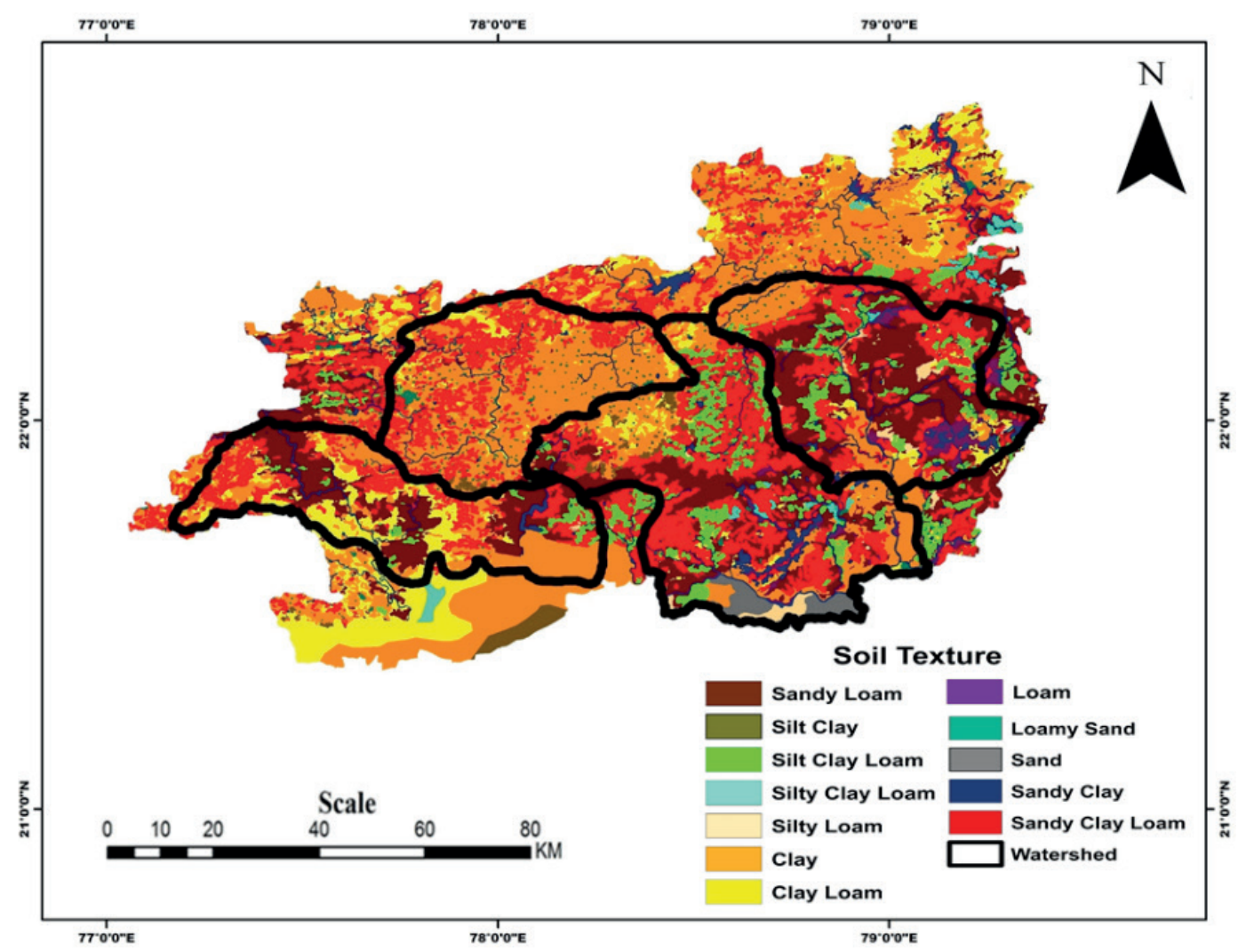

Fig. 7. Distribution of soil in the selected study area 


\section{Drainage density}

In hydrological studies, drainage density is an important parameter because of its direct relation to the slope and an inverse relationship with permeability (Ghosh and Jana 2017). Drainage density represents the ratio between stream length and unit area of the basin (Strahler 1952). It indicates the total volume of streams in a watershed. Drainage density is heterogeneous because of variation in lithology, relief, slope, and precipitation from one region to another. In this paper, drainage density has been categorized into five classes (Fig. 8). Areas with higher drainage density indicate a favourable condition for the surface runoff; therefore, it is deemed a low-potential groundwater zone. Thus, regions with low drainage density are given high weightage and vice versa.

\section{Lineament density}

As detected in satellite images simple or complex properties of a linear geological structure such as faults, joints, fractures, or any other discontinuities on the surface are considered lineaments. Lineaments in the study area have aligned into NW-SE, NE-SW, NNE-SSE, and ENE-WSW direction. Lineament density, intersection point, and lineaments along the drainage lines are essential factors for determining groundwater potential in any area, as they are used as a tool to understand the occurrence and movement of the groundwater in hard rock terrain.

The lineament density of the study area was grouped into five classes (Fig. 9). The high lineament density areas (from 0.69 $\mathrm{km} / \mathrm{sq} . \mathrm{km}$ to $1.29 \mathrm{~km} / \mathrm{sq} . \mathrm{km}$ ) are thereby assigned the highest weightage values in assessing the groundwater prospect zones of the Betul-Chhindwara region whereas the low weight is assigned to low-density areas (0 km/sq. km to 0.17 km/sq. km) (Table 4).

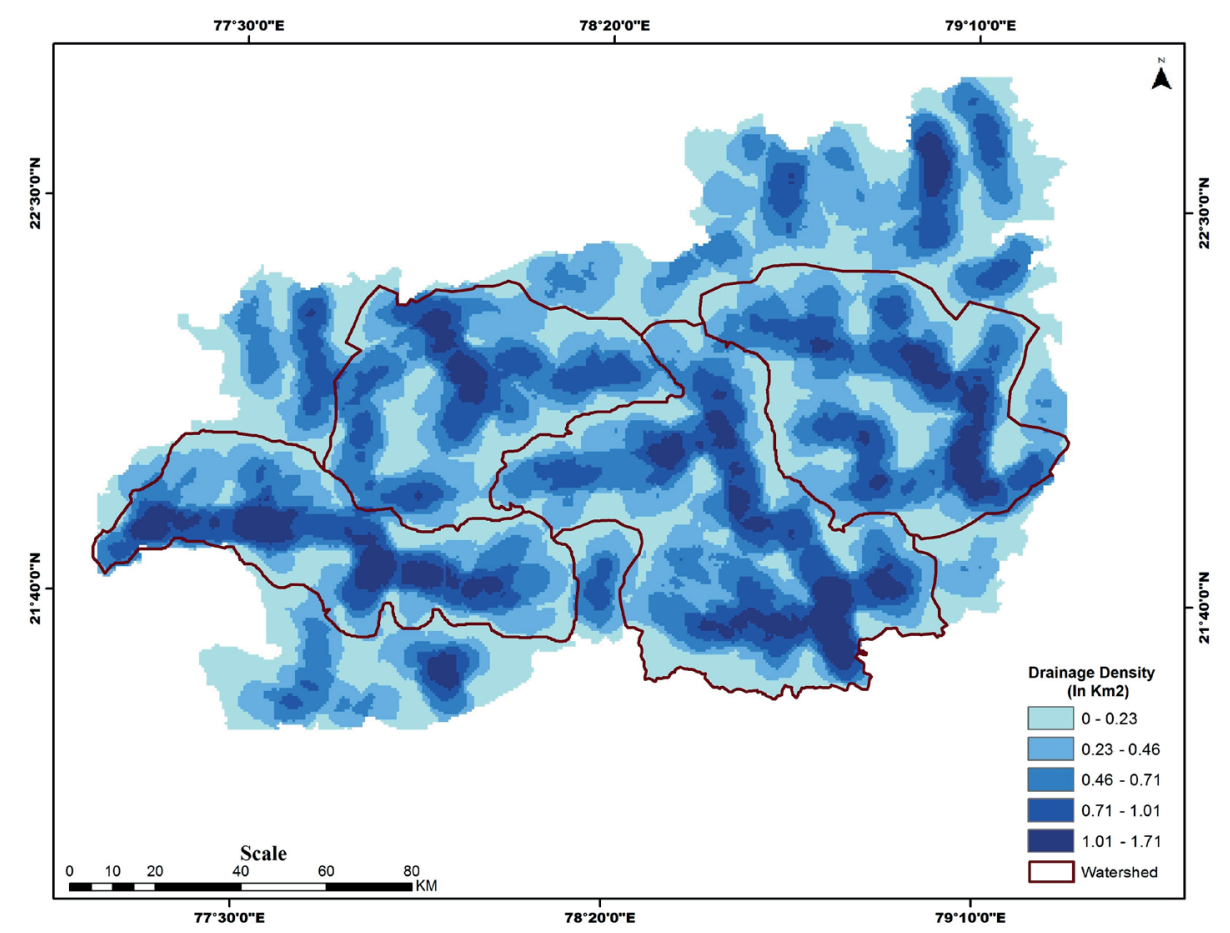

Fig. 8. Drainage density map of the selected study area

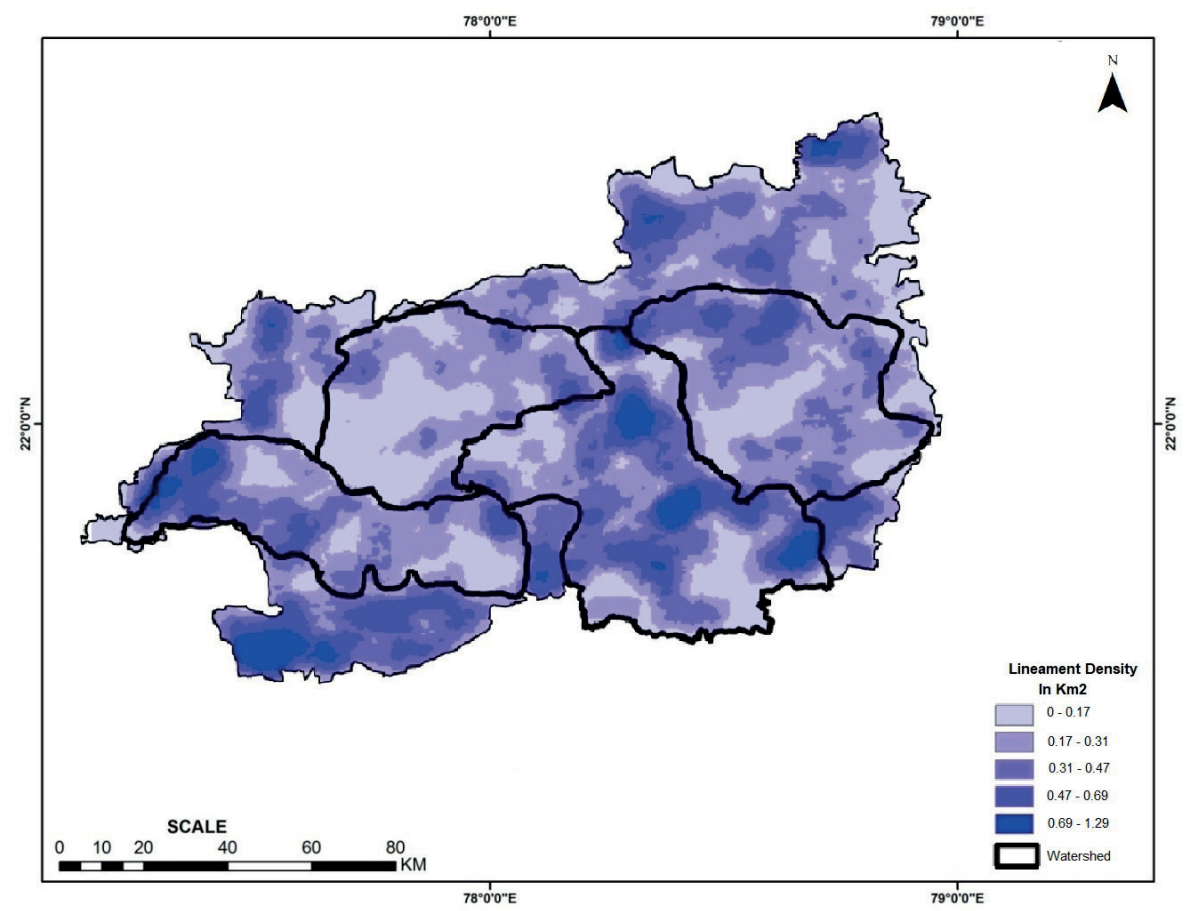

Fig. 9. Lineament density map of the selected study area 


\section{Slope}

The study area's slope ranges from 0 degrees to 65 degrees and has been categorized into five classes (Fig.10). Most of the region (72.87\% of total area of the region) comes under a 10-degree slope. An area with a gentle slope (0-5 degrees) could be useful for groundwater potential because the slope directly relates to runoff while we established an inverse relationship with the infiltration rate. The high slope class is assigned low weight whereas the low slope is given high weightage as per its responses on groundwater occurrence.

Land use and land cover (LULC)

LULC influences hydrological cycle and fluctuation of the water table and groundwater occurrence (Cook et al.
1989; Phillips 1994; Tyler et al. 1996; Pandey and Dwivedi 2014). Many investigations related to groundwater recharge and its impact on LULC have been conducted to understand the hydrological behaviour (Roark and Healy, 1998). Land use/land cover is directly associated with factors controlling the groundwater recharge, such as soil, vegetation, slope, rainfall, etc. Seven land use/ land cover classes were recognized as sparse forest, dense forest, cropland, waterbody, fallow land, settlement, and barren land (Fig.11). Waterbody, dense forest, sparse forest, and cropland area have good groundwater potential. Therefore, maximum weightage is given these classes while barren land, settlement, and fallow land have an inadequate response to groundwater recharge to assign low weightage to these features.

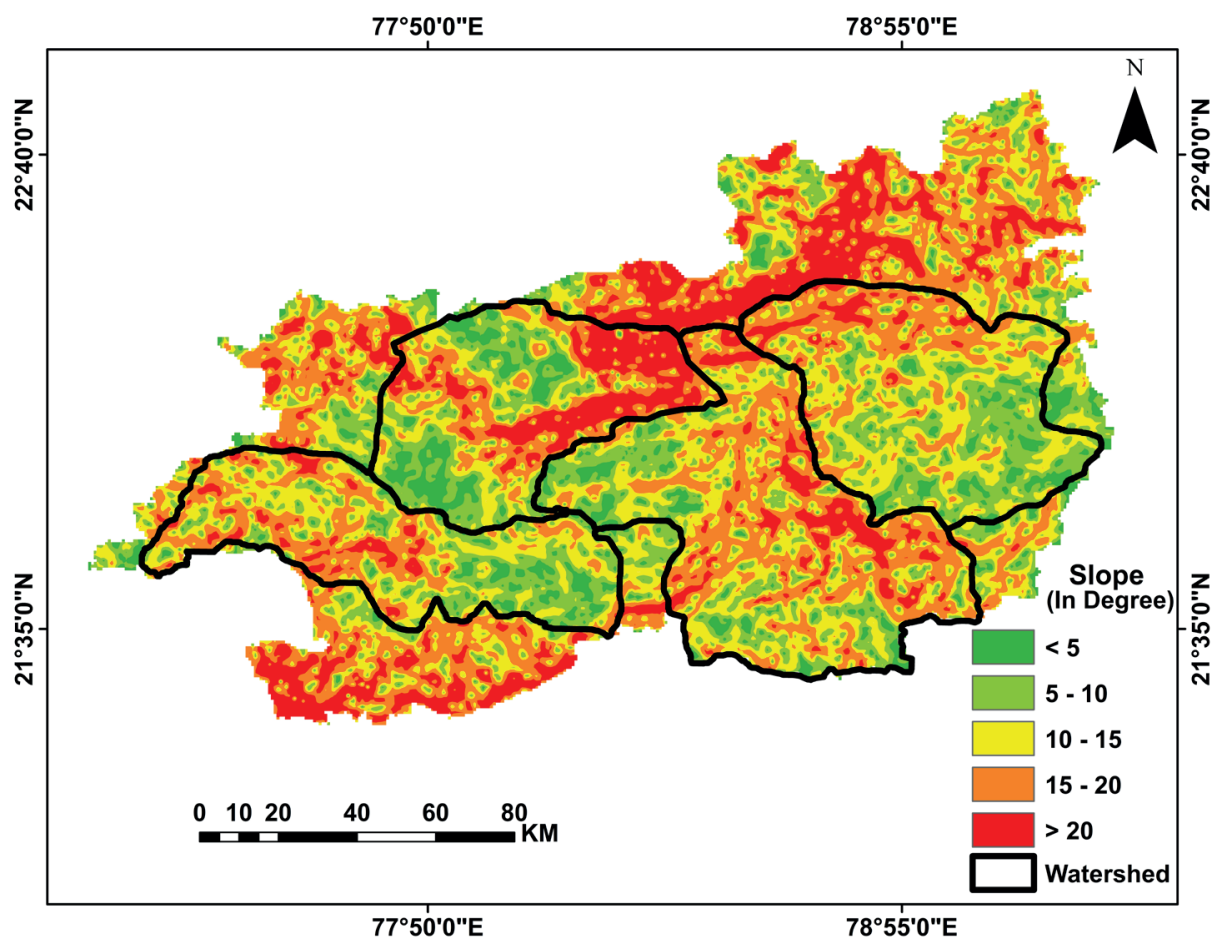

Fig.10. Variation of slope in the selected study are

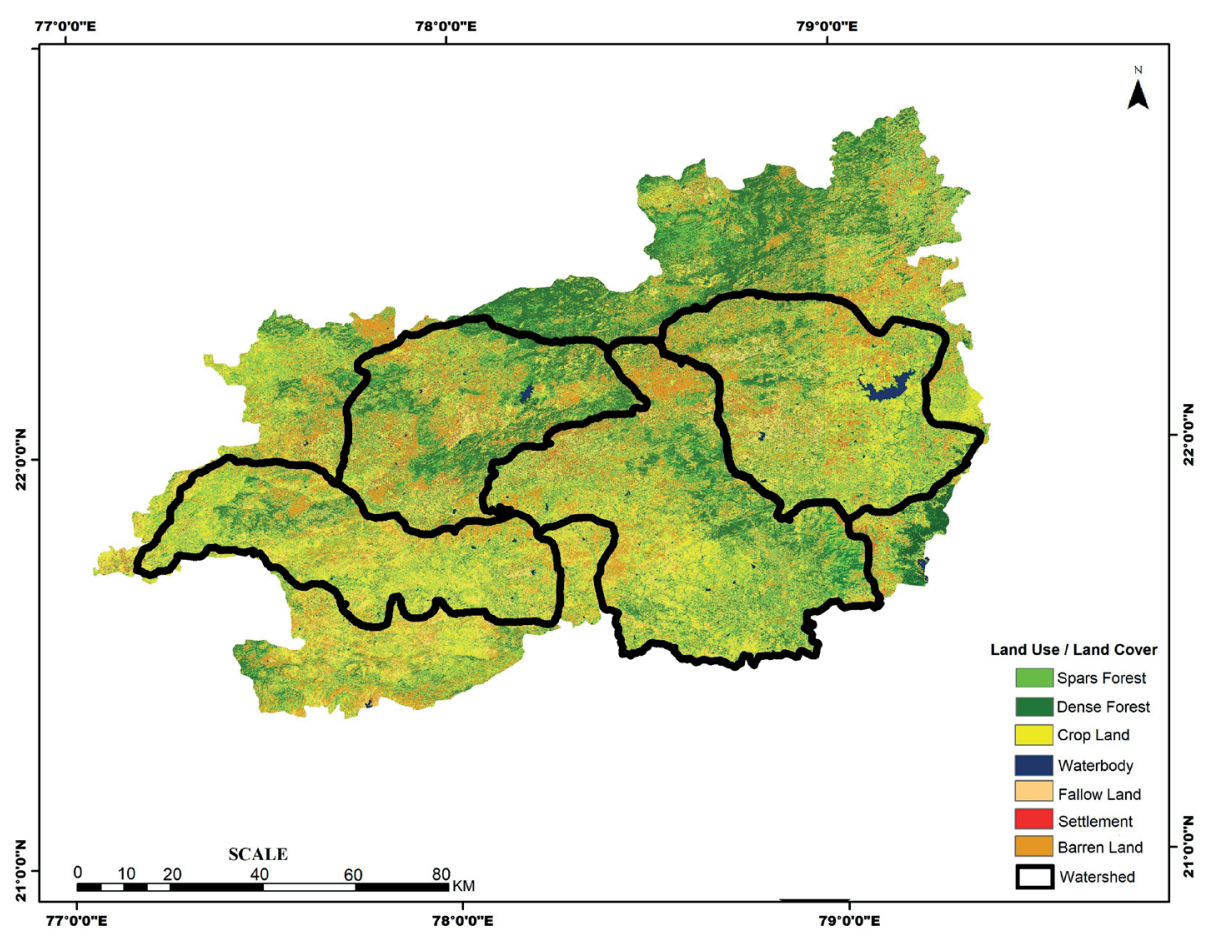

Fig. 11. Land use / land cover map of the selected study area 


\section{Groundwater depth}

The map showing the groundwater level of the premonsoon season was developed using the groundwater level data.

Fig. 12: Groundwater depth map of the selected study area During the pre-monsoon season, the average depth of the water level varies from $<5 \mathrm{~m}$ to $>35 \mathrm{~m}$. The northern part of the study area is characterized by a good water level in comparison to other regions. On the obtained groundwater level map the study area is divided into eight sub-classes (Fig. 12).

\section{Weights assignment using AHP}

A three-level hierarchy of goals, criteria attributes, and alternatives was considered to demonstrate the spatial AHP procedure and to evaluate potential groundwater zones. Ten thematic layers such as geomorphology, geology, rainfall, lineament, drainage density, physiography, soil, slope, groundwater level, and LULC were selected for assessing the status of groundwater availability in the study region. The weightage assigned to these layers is based on their role in the occurrence of potential zones of groundwater in the study region.

The methodology, which was adopted to execute AHP, mainly consists of (a) development of a GIS digital database, which included all spatial information (b) determination of the criteria of evaluation and hierarchical structure formation and criteria of multiple formations (c) implementation of the AHP method in the calculation of the criteria relative importance weights; and (d) implementation of the weight - sum method (WSM) in the estimation of potential groundwater zones.

\section{Generation of comparison matrix}

The (1-9) Scale of Thomas L. Saaty determines the relative importance values.

(a) Indication of the score as one (1) means that both the themes are equal in importance whereas the indication of the score as nine (9) means that one theme is more significant in comparison to the other (Saaty, 1980)

(b) Matrix is constructed by assigning the values from 1 to 9 to each layer's relative importance. The basic concept is that if the ' $x$ ' layer is more important than the ' $Y$ ' layer, then the assigned value will be 9. Meanwhile, ' $Y$ ' will be less important than ' $X$ ', then the value assigned will be 1/9 (Saaty 1980). The matrix is shown in Table 2.

(c) After assigning relative weight, the vector of weight (Eigen value) was calculated on a judgment base (Saaty, 1980)

(d) Finally, the Consistency Index (CI) is derived using the Equation-1 S (Saaty 1980) -

$$
C I=(\lambda \max -n) /(n-1)
$$

' $\lambda$ max' indicates the largest Eigenvalue of matrix and ' $n$ ' indicates the total classes. After calculating the Eigen value of the matrix the largest value was 11.21, which represents $\lambda$ max. Consistency Ratio (CR) was calculated using Equation 2.

$$
C R=(C I) /(R I)
$$

Consistency Index (Cl) computed by equation

$(1)=(11.21-10) /(10-1)=0.134$

Consistency Ratio $(C R)=(0.134) /(1.49)=0.0835$

$\mathrm{Rl}$ indicates the Random Consistency Index, which varies upon the order of the matrix (Table 3). Saaty (1980) suggests that if the ' $C R$ ' value is lesser or equivalent to 0.1 , the inconsistency is reliable. The consistency of the matrix in the present study was tested to confirm the consistency of decisions in the pair-wise comparison, wherein the value of CR was computed to be 0.083 , which is less than 0.1 .

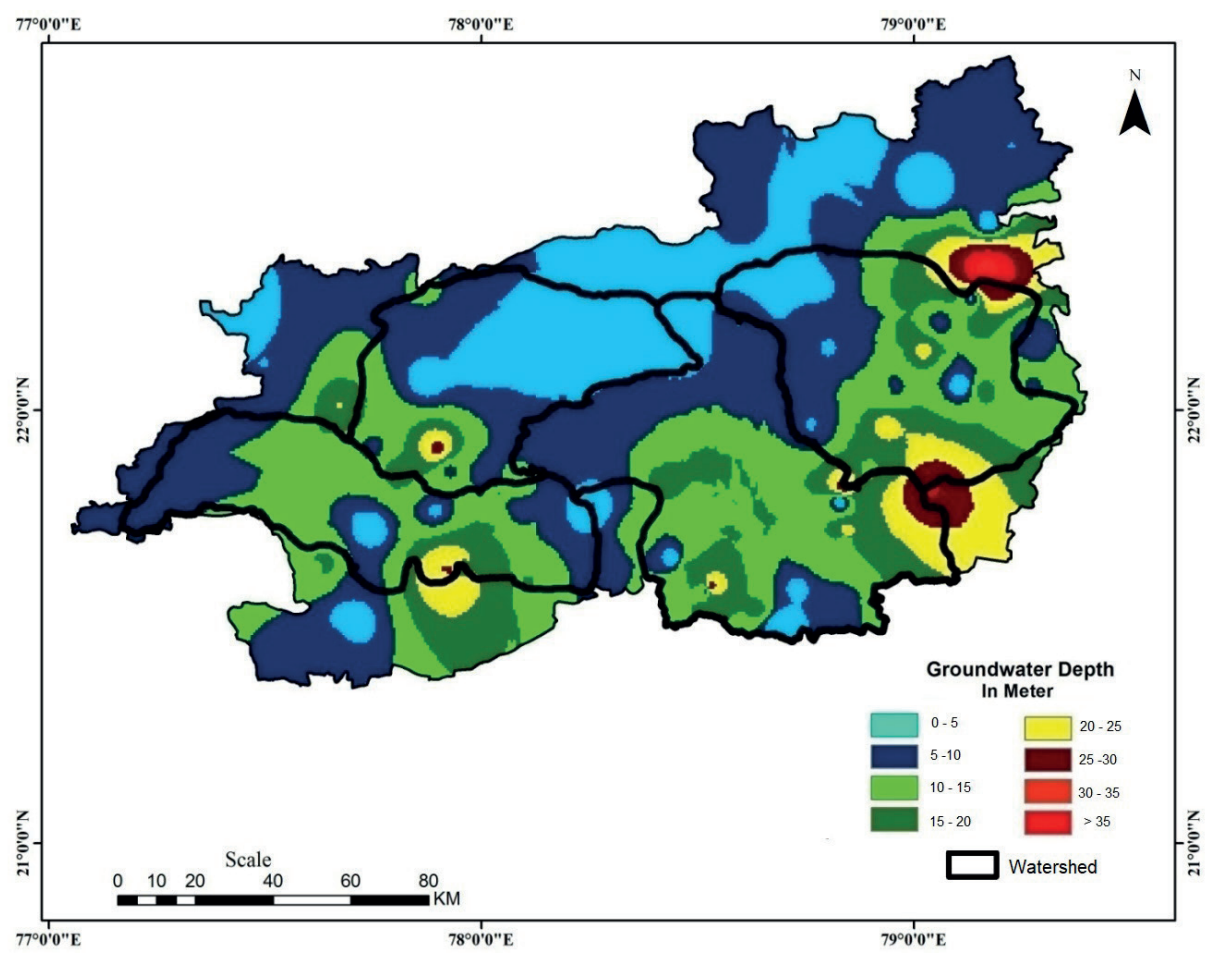

Fig. 12. Groundwater depth map of the selected study area

Table 1. Scale of Saaty (1-9)

\begin{tabular}{|c|c|c|c|c|c|c|c|c|}
\hline Scale & 1 & 2 & 3 & 4 & 5 & 6 & 7 & 8 \\
\hline Importance & $\begin{array}{c}\text { Equal } \\
\text { importance }\end{array}$ & Weak & $\begin{array}{c}\text { Moderate } \\
\text { importance }\end{array}$ & $\begin{array}{c}\text { Moderate } \\
\text { plus }\end{array}$ & $\begin{array}{c}\text { Strong } \\
\text { importance }\end{array}$ & $\begin{array}{c}\text { Strong plus } \\
\text { impory strong } \\
\text { importance }\end{array}$ & $\begin{array}{c}\text { Very, very } \\
\text { strong }\end{array}$ & $\begin{array}{c}\text { Extreme } \\
\text { importance }\end{array}$ \\
\hline
\end{tabular}


When obtaining the pair-wise comparison matrix according to the preference values (Table 2), the matrix was analyzed to find each criterion's performance ratings in achieving the related weights. The normalized weights are obtained by using the Weight Sum Model (WSM), which computes the Groundwater Potential Index (GWPI) by multiplying AHP weights with the corresponding ratings (Equation 3).

\section{Overlay analysis}

The groundwater potential index (GWPI) in this study is computed using the WSM method (Malczewski 1999; Machiwalet al.2011) and is shown in Equation 3.

$$
G W P I=\sum_{i=1}^{n} \sum_{j=1}^{m}\left[a_{i}\left(\beta_{i j} x_{i j}\right)\right]
$$

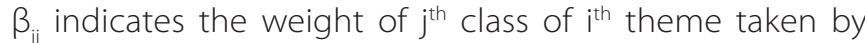
AHP and ai shows the weight of ith theme, while ' $n$ ' and ' $m$ ' denotes the total number of thematic layers classes in the thematic layer and $x_{i j}$ represent the value of a pixel of $j^{\text {th }}$ class of $i^{\text {th }}$ theme.

\section{Table 2. Pair-wise comparison matrix of thematic layers, weight sum, and consistency ratio}

\begin{tabular}{|c|c|c|c|c|c|c|c|c|c|c|c|c|}
\hline Parameter & Geomorphology & Rainfall & Geology & Physiography & Soil & $\begin{array}{c}\text { Drainage } \\
\text { density }\end{array}$ & $\begin{array}{c}\text { Lineament } \\
\text { density }\end{array}$ & Slope & LU/LC & $\begin{array}{c}\text { Groundwater } \\
\text { depth }\end{array}$ & $\begin{array}{c}\text { Weighted } \\
\text { sum }\end{array}$ & $\begin{array}{c}\text { Consistency } \\
\text { ratio }\end{array}$ \\
\hline Geomorphology & 1 & 1.125 & 1.285 & 1.384 & 1.5 & 1.636 & 1.8 & 2.25 & 2.571 & 3 & 17.55 & 6.38 \\
\hline Rainfall & 0.888 & 1 & 1.142 & 1.230 & 1.333 & 1.454 & 1.6 & 2 & 2.285 & 2.666 & 15.60 & 7.18 \\
\hline Geology & 0.777 & 0.875 & 1 & 1.076 & 1.166 & 1.272 & 1.4 & 1.75 & 2 & 2.333 & 13.65 & 8.21 \\
\hline Physiography & 0.722 & 0.812 & 0.928 & 1 & 1.083 & 1.181 & 1.3 & 1.625 & 1.857 & 2.166 & 12.67 & 8.84 \\
\hline Soil & 0.666 & 0.75 & 0.857 & 0.923 & 1 & 1.090 & 1.2 & 1.5 & 1.714 & 2 & 11.70 & 9.58 \\
\hline $\begin{array}{c}\text { Drainage density } \\
\begin{array}{c}\text { Lineament } \\
\text { density }\end{array}\end{array}$ & 0.611 & 0.687 & 0.785 & 0.846 & 0.916 & 1 & 1.1 & 1.375 & 1.571 & 1.833 & 10.72 & 10.45 \\
\hline $\begin{array}{c}\text { Slope } \\
\text { LU/LC }\end{array}$ & 0.454 & 0.625 & 0.714 & 0.769 & 0.833 & 0.909 & 1 & 1.25 & 1.428 & 1.666 & 9.75 & 11.5 \\
\hline $\begin{array}{c}\text { Groundwater } \\
\text { depth }\end{array}$ & 0.333 & 0.5 & 0.571 & 0.615 & 0.666 & 0.727 & 0.8 & 1 & 1.142 & 1.333 & 7.80 & 14.37 \\
\hline
\end{tabular}

Table 3. Saaty's Ratio Index for Different Values of ' $n$ '

\begin{tabular}{|c|c|c|c|c|c|c|c|c|c|c|}
\hline $\mathrm{n}$ & 1 & 2 & 3 & 4 & 5 & 6 & 7 & 8 & 9 & 10 \\
\hline Ratio Index & 0 & 0 & 0.58 & 0.89 & 1.12 & 1.24 & 1.32 & 1.41 & 1.45 & 1.49 \\
\hline
\end{tabular}

Table 4. Assigned weightages of thematic layers and normalized weights and rank

\begin{tabular}{|c|c|c|c|c|c|c|}
\hline Thematic parameters & Sub-classes & Weight & Normalized weight & Rank & Area $\left(\mathrm{km}^{2}\right)$ & Area (\%) \\
\hline \multirow[t]{7}{*}{ Geomorphology } & Highly dissected plateau & 1 & 0.047 & 0.156 & 2121.95 & 9.69 \\
\hline & Moderately dissected plateau & 2 & 0.09 & & 7742.83 & 35.36 \\
\hline & Lowly dissected plateau & 3 & 0.14 & & 72.06 & 0.32 \\
\hline & Pediment pediplain complex & 4 & 0.19 & & 9542.65 & 43.58 \\
\hline & Dissected hills and valleys & 1 & 0.047 & & 2044.05 & 9.33 \\
\hline & Alluvial plain & 5 & 0.23 & & 31.69 & 0.14 \\
\hline & Dam and reservoir & 5 & 0.23 & & 341.41 & 1.55 \\
\hline \multirow[t]{9}{*}{ Rainfall (mm) } & $550-600$ & 4 & 0.06 & 0.139 & 1965.9 & 8.96 \\
\hline & $601-650$ & 5 & 0.07 & & 3545.8 & 16.17 \\
\hline & $651-700$ & 6 & 0.09 & & 3939.4 & 17.96 \\
\hline & $701-750$ & 7 & 0.10 & & 3279.7 & 14.95 \\
\hline & $751-800$ & 8 & 0.12 & & 2268.7 & 10.34 \\
\hline & $801-850$ & 8 & 0.12 & & 4524.3 & 20.63 \\
\hline & $851-900$ & 8 & 0.12 & & 556.0 & 2.53 \\
\hline & $900-950$ & 9 & 0.14 & & 567.3 & 2.58 \\
\hline & $>950$ & 9 & 0.14 & & 1276.9 & 5.82 \\
\hline \multirow[t]{5}{*}{ Geology } & Upper Gondwana & 3 & 0.14 & 0.121 & 1309.94 & 5.98 \\
\hline & Lower Gondwana & 4 & 0.19 & & 2481.22 & 11.33 \\
\hline & Recent alluvium & 6 & 0.28 & & 490.945 & 2.24 \\
\hline & Deccan trap & 2 & 0.095 & & 14309.9 & 65.35 \\
\hline & Older alluvium / Laterite & 5 & 0.24 & & 18.2458 & 0.08 \\
\hline
\end{tabular}




\begin{tabular}{|c|c|c|c|c|c|c|}
\hline & bundelkhand granite / gneiss & 1 & 0.047 & & 3285.89 & 15.0 \\
\hline \multirow[t]{8}{*}{ Physiography } & Betul plateau & 6 & 0.214 & 0.113 & 6679.6 & 30.50 \\
\hline & Chhindwara plateau & 6 & 0.214 & & 5185.93 & 23.68 \\
\hline & Amarwara & 5 & 0.178 & & 2964.19 & 13.54 \\
\hline & Gawilgarh hill & 1 & 0.035 & & 1506.36 & 6.87 \\
\hline & Kalibhit hill and Marabdi plateau & 2 & 0.071 & & 1947.48 & 8.89 \\
\hline & Pachmari hill & 1 & 0.035 & & 1391.14 & 6.35 \\
\hline & Sausar upland & 3 & 0.107 & & 1176.04 & 5.39 \\
\hline & Upper Kanhan valley & 4 & 0.143 & & 1048.05 & 4.78 \\
\hline \multirow[t]{12}{*}{ Soil } & Clay loam & 1 & 0.017 & 0.104 & 2856.83 & 12.95 \\
\hline & Sandy loam & 9 & 0.157 & & 4515.53 & 20.48 \\
\hline & Loam & 6 & 0.105 & & 423.479 & 1.92 \\
\hline & Clay & 1 & 0.017 & & 7157.8 & 32.46 \\
\hline & Sandy clay loam & 4 & 0.701 & & 4712.13 & 21.37 \\
\hline & Silt clay loam & 3 & 0.052 & & 1014.85 & 4.60 \\
\hline & Silty loam & 5 & 0.087 & & 144.43 & 0.65 \\
\hline & Silt loam clay & 2 & 0.035 & & 111.19 & 0.50 \\
\hline & Loamy sand & 8 & 0.140 & & 179.168 & 0.81 \\
\hline & Sand & 10 & 0.175 & & 209.839 & 0.95 \\
\hline & Sandy clay & 7 & 0.122 & & 537.747 & 2.43 \\
\hline & Silt clay & 1 & 0.017 & & 182.272 & 0.82 \\
\hline \multirow[t]{6}{*}{ Drainage density } & $0-0.234$ & 5 & 0.333 & 0.095 & 6324.03 & 29.09 \\
\hline & $0.234-0.469$ & 4 & 0.266 & & 6392.194 & 29.41 \\
\hline & $0.469-0.717$ & 3 & 0.200 & & 4445.615 & 20.45 \\
\hline & $0.717-1.012$ & 2 & 0.133 & & 3182.322 & 14.64 \\
\hline & $1.012-1.710$ & 1 & 0.066 & & 1389.074 & 06.39 \\
\hline & $0-0.177$ & 1 & 0.066 & & 5169.97 & 23.63 \\
\hline \multirow[t]{4}{*}{ Lineament density } & $0.177-0.314$ & 2 & 0.133 & 0.086 & 7789.42 & 35.61 \\
\hline & $0.314-0.471$ & 3 & 0.200 & & 5601.32 & 25.64 \\
\hline & $0.471-0.699$ & 4 & 0.266 & & 2614.43 & 11.95 \\
\hline & $0.699-1.292$ & 5 & 0.333 & 0.069 & 695.14 & 3.17 \\
\hline \multirow[t]{5}{*}{ Slope } & $<5$ & 5 & 0.416 & & 8669.27 & 39.59 \\
\hline & $5-10$ & 3 & 0.250 & & 7287.64 & 33.28 \\
\hline & $10-15$ & 2 & 0.166 & & 3717.64 & 16.97 \\
\hline & $15-20$ & 1 & 0.083 & & 1669.73 & 7.62 \\
\hline & $>20$ & 1 & 0.083 & & 552.18 & 2.54 \\
\hline \multirow[t]{7}{*}{ LU/LC } & Dense forest & 6 & 0.272 & 0.060 & 5129.75 & 23.41 \\
\hline & Sparse forest & 5 & 0.227 & & 2705.55 & 12.34 \\
\hline & Crop land & 4 & 0.181 & & 5023.48 & 22.93 \\
\hline & Fallow land & 3 & 0.136 & & 4214.59 & 19.23 \\
\hline & Water body & 7 & 0.31 & & 160.248 & 0.73 \\
\hline & Settlement & 1 & 0.045 & & 308.236 & 1.40 \\
\hline & Barren land & 1 & 0.045 & & 4365.79 & 19.92 \\
\hline \multirow[t]{8}{*}{ Groundwater depth } & $0-5$ & 8 & 0.22 & 0.052 & 3864.47 & 17.65 \\
\hline & $5-10$ & 7 & 0.19 & & 8226.77 & 37.58 \\
\hline & $10-15$ & 6 & 0.16 & & 5552.11 & 25.36 \\
\hline & $15-20$ & 5 & 0.14 & & 2667.75 & 12.18 \\
\hline & $20-25$ & 4 & 0.11 & & 1114.61 & 05.09 \\
\hline & $25-30$ & 3 & 0.08 & & 373.588 & 01.71 \\
\hline & $30-35$ & 2 & 0.05 & & 75.5539 & 0.35 \\
\hline & $35>$ & 1 & 0.02 & & 18.4908 & 0.08 \\
\hline
\end{tabular}


Finally, the themes were rasterized based on their evaluated normalized weights in the GIS platform for measuring the prospective groundwater area of the Betul-Chhindwara region. The layers were overlaid using a spatial analysis tool in ArcGIS software to appraise the potential groundwater zones. The obtained potential areas have been categorized into five zones: very good, good, moderate, poor, and very poor prospect zone (Fig. 13).

\section{Validation with actual yield data}

The result was validated by evaluating the relationship between the obtained result and the actual yield data collected from 16 wells from various locations of the study area. The location of wells with yield information is shown on the map (Fig.14). Actual yield has been classified into five classes: below 5 m.bgl. (very good), from 5 m.bgl. to 10 m.bgl. (good), from 10 m.bgl. to $15 \mathrm{~m}$. bgl. (moderate), from 15 m.bgl. to 20 m.bgl. (poor), and above $20 \mathrm{~m} . \mathrm{bgl}$. (very poor). The classification is based on the shared information collected from the field hydrogeologist working in the study area. Validation was completed through the successful evaluation of prospect zone maps and actual yield data of wells (details are shown in Table 5).

Expected accuracy indicators are as follows Claimed total well location of yield for accuracy estimation $=16$

Satisfied well location on the reference map (groundwater prospect map) $=12$

Unsatisfied well location on the reference map $=04$

Predicted accuracy $=$ (satisfied well location) /

(claimed total well location) * 100

Predicted accuracy $=12 / 16^{*} 100=75 \%$

Predicted accuracy reflects that the AHP method is suitable for the identification of groundwater potential zone mapping.

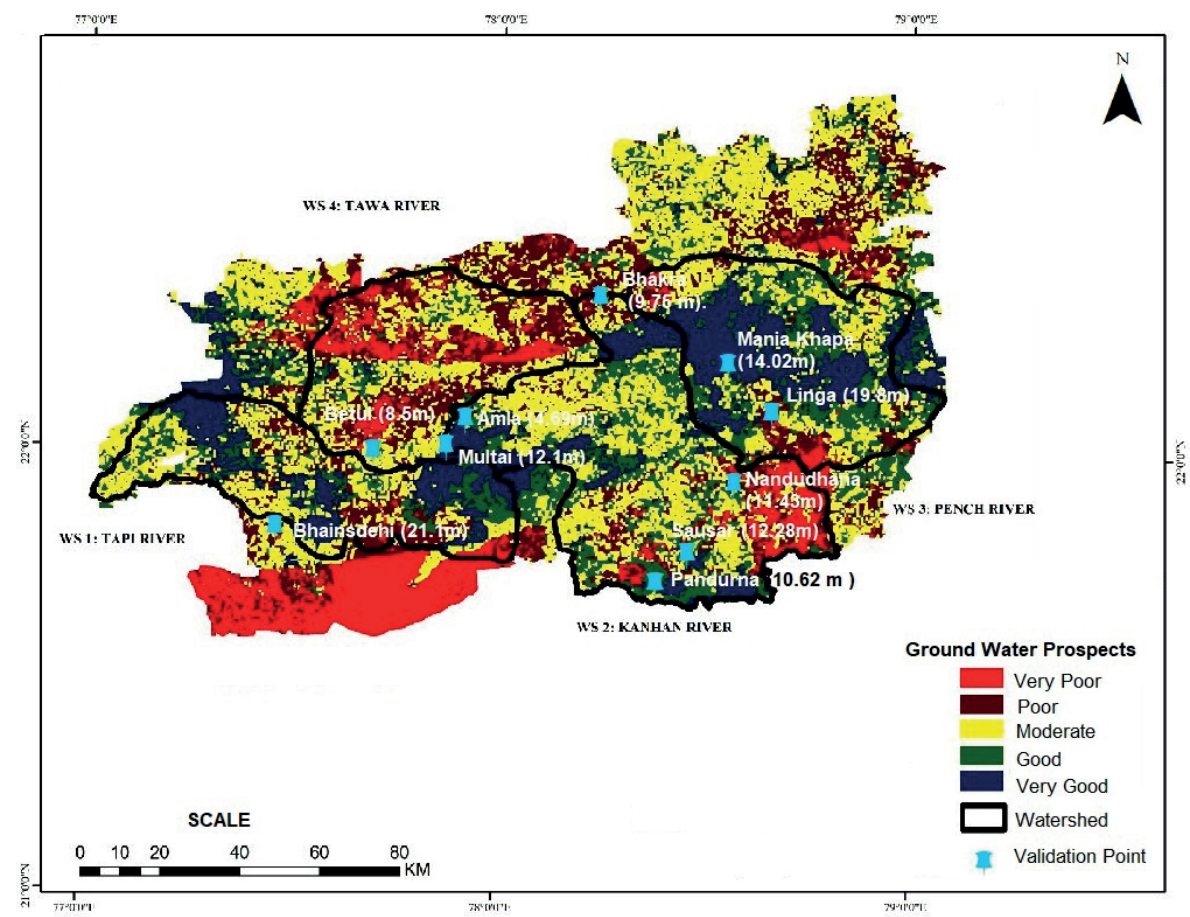

Fig. 13. Groundwater prospect zones of the region and field validation point

Table 5. Actual yield from observation well point during the Field Visit

\begin{tabular}{|c|c|c|c|c|c|c|c|}
\hline S.N. & Lat (N) & Long (E) & Area & $\begin{array}{l}\text { Actual yield } \\
(\mathrm{mbgl})\end{array}$ & $\begin{array}{l}\text { Description } \\
\text { of yield data }\end{array}$ & $\begin{array}{l}\text { Expected yield description } \\
\text { for prospect map }\end{array}$ & $\begin{array}{l}\text { Validation between actual } \\
\text { yield and expected yield }\end{array}$ \\
\hline 1 & 21.964827 & 78.92926 & Linga & 19.8 & Low & Low & Satisfied \\
\hline 2 & 21.538921 & 78.643784 & Pandurna & 10.62 & Good & Moderate & Dissatisfied \\
\hline 3 & 21.572483 & 78.707146 & Gangatwara & 10.66 & Good & Good & Satisfied \\
\hline 4 & 21.599154 & 78.74572 & Sausar & 18.28 & Poor & Poor & Satisfied \\
\hline 5 & 21.767147 & 78.828255 & Nandudhana & 11.43 & Moderate & Moderate & Satisfied \\
\hline 6 & 22.081533 & 78.853058 & Mania Khapa & 14.02 & Moderate & Moderate & Satisfied \\
\hline 7 & 22.219461 & 78.477982 & Bhakra & 9.75 & Good & Moderate & Dissatisfied \\
\hline 8 & 21.64444 & 77.63667 & Bhainsdehi & 21.1 & very poor & very poor & Satisfied \\
\hline 9 & 21.92361 & 78.12417 & Amla & 5.69 & Very good & very good & Satisfied \\
\hline 10 & 21.84667 & 78.09194 & Multai & 12.1 & Moderate & very Good & Dissatisfied \\
\hline 11 & 21.76861 & 77.89389 & Betul & 8.5 & Good & Moderate & Dissatisfied \\
\hline 12 & 22.348139 & 78.662231 & Tamia & 11.8 & Moderate & Moderate & Satisfied \\
\hline 13 & 22.386095 & 78.777107 & Sidauli & 18.3 & Poor & Poor & Satisfied \\
\hline 14 & 22.192768 & 78.598717 & Junnardeo & 14.5 & Moderate & Moderate & Satisfied \\
\hline 15 & 22.014781 & 77.672993 & Chicholi & 12.6 & Moderate & Moderate & Satisfied \\
\hline 16 & 22.289212 & 79.170394 & Amarwada & 13.2 & Moderate & Moderate & Satisfied \\
\hline
\end{tabular}




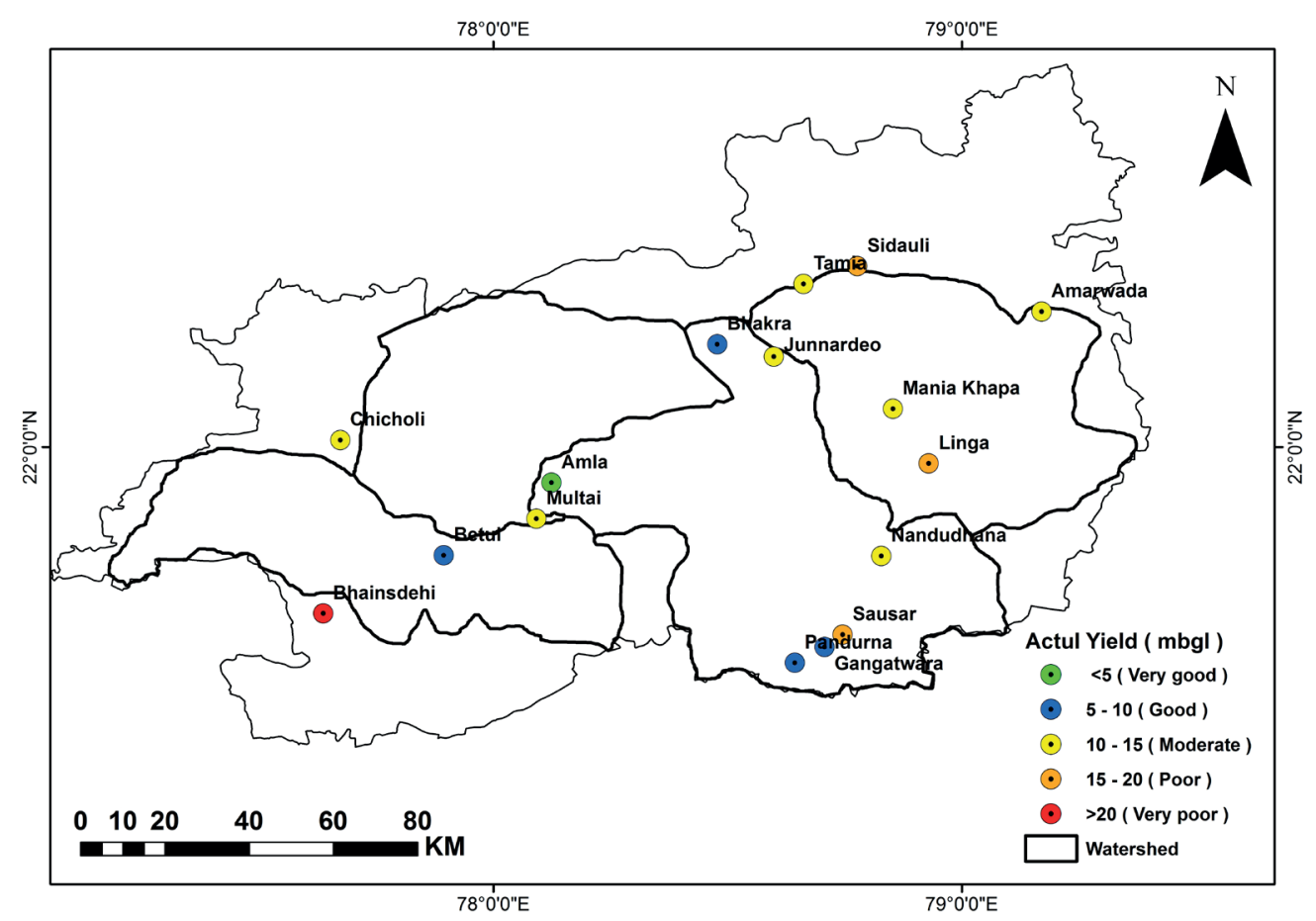

Fig. 14. Field observation points

\section{Results and discussion}

The results show that groundwater potential on twothirds of the study area varies from moderate to very good. Among them very good potential zone covers $15.22 \%$ (3262.191 sq.km), good potential zone covers $22.46 \%$ (4815.35 sq. km), and moderate groundwater potential zone covers $29.96 \%$ (6423.02 sq.km) of the study area whereas approximately one-third of the study area has poor (22.65\% or 4857.26 sq.km) and very poor $(09.71 \%$, 2082.975 sq.km) groundwater potential. Figure13 shows that out of the four watersheds in the Betul-Chhindwara region, the WS 1 (watershed of the Tapi river) was ranked the second that corresponds to a very good groundwater potential zone. It was noted that groundwater potential zone in the maximum areas of the Tapi river watershed varies from a very good to good. On the other hand, the maximum regions of WS 2 (the Kanhan river watershed) belong to moderate groundwater potential zones. The WS 3 is the Pench river watershed, which has a considerable extent of very good groundwater potential zones; however, groundwater prospect zones in the lower watershed regions vary from low to very low. The groundwater potential zones of the Tawa river watershed (WS 4) mostly vary from moderate to very low. Therefore, to establish a balance between high and low potential zones concerning water resource utilization is an urgent task.

The results reveal that low and medium groundwater potential areas are suffering from the severe scarcity of water and fail to meet the demand for freshwater in the region. The water resource of these regions needs to be urgently and properly managed. The outcome of the present inventory study can be used as the basis for further planning of the sustainable development and management of water resources and solving issues related to water resources.

The study focuses on hard rock, which is characterized by low porosity and permeability hence the study area faces water scarcity due to high runoff, less annual rainfall, etc. There is a strong need to adopt different rainwater harvesting structures and artificial recharge structures such as Check Dams, Nala Bunds, Percolation Tanks, Injection Wells, Induced Recharge, Contour Bunding, Contour Trenching, and Gully Plugging as per geological and topographical conditions to improve the groundwater conditions of the study area. The structures mentioned above need to be developed in the places where groundwater potential is low, whereas high potential zones can be used for extraction, drinking, and irrigation purposes (Table 6).

Table 6. Actual yield from observation well point during the field visit

\begin{tabular}{|c|c|c|c|c|}
\hline \multirow{2}{*}{ No. } & \multicolumn{3}{|c|}{ Groundwater potential zone } & \multirow{2}{*}{$\begin{array}{l}\text { Suitable zone and critical zone for groundwater development and } \\
\text { management }\end{array}$} \\
\hline & Zone & Area covered & Area percentage & \\
\hline 1. & Very good & 3262.191 sq.km & $15.22 \%$ & Suitable for goundwater extraction \\
\hline 2. & Good & 4815.35 sq.km & $22.46 \%$ & Suitable for goundwater extraction \\
\hline 3. & Moderate & $6423.02 \mathrm{sq} \cdot \mathrm{km}$ & $29.96 \%$ & $\begin{array}{l}\text { Suitable for groundwater extraction and recharge as per the needs of the } \\
\qquad \text { area }\end{array}$ \\
\hline 4. & Poor & 4857.26 sq.km & $22.65 \%$ & $\begin{array}{c}\text { Critical zone and an urgent need for groundwater recharge through } \\
\text { harvesting structures }\end{array}$ \\
\hline 5. & Very poor & 2082.975 sq.km & $09.71 \%$ & $\begin{array}{c}\text { Critical zone and an urgent need for groundwater recharge through } \\
\text { harvesting structures }\end{array}$ \\
\hline & Total & $21440.8 \mathrm{sq} . \mathrm{km}$ & $100.00 \%$ & \\
\hline
\end{tabular}


Agriculture is the main economic activity in the BetulChhindwara region therefore there is high water demand for irrigation. Because of easy and timely accessibility, ubiquitous availability, and cheap drafting technology, groundwater is a significant source of water supply not only for drinking and domestic purposes but also for irrigation. Since water is a vital resource for the use and maintenance of other resources, it can only be developed to a certain extent without affecting other resources and ecological conditions. It is also highly variable across the study area. Therefore, it is crucially essential that this resource is developed and managed sustainably.

This study found that a gentle slope with low drainage density gives more scope for high groundwater development. There is a need to adopt proper artificial recharge practice with geological and topographical consideration in the region as most of the area possesses adequate groundwater recharge capacity.

\section{CONCLUSIONS}

The groundwater potential zones mapping is beneficial for sustainable groundwater development and management planning. The present study fulfils these necessities. The need for groundwater resources is high, but due to rocky terrain, their availability is limited. In this study, favourable zones for groundwater occurrence and storage were delineated based on various thematic layers such as geomorphology, geology, physiography, rainfall, soil, slope, lineament, drainage density, and groundwater depth and land use/land cover of this region. This study expressed the competences of remote sensing and GIS and the integration of analytical hierarchy process techniques to identify potential groundwater zones in the BetulChhindwara region. The obtained result is validated with groundwater well yield data to ensure that the obtained result is accurate.

There is wide spatial variation in groundwater resources in the region. Only one-third of the area possesses high and very high potential, and hence it is safe to plan sustainable use of water in those areas. The high groundwater potential areas may be used with the help of modern technology to optimize the use and to reduce the wastage and misuse of water while the needs of the low groundwater potential areas can be met with conjunctive use of groundwater with surface water for reducing pressure on groundwater resource. At the same time, measures to improve groundwater potential must be taken in these areas. Possibilities of transfer of water from high potential areas to low potential areas can also be explored. Thus, the outcome of the present inventory study may be used as the basis for further planning of the sustainable development and management of water resources and solving issues related to water resources.

Because of the nature of the distribution and degree of the potentiality of groundwater in the region, it is evident that there is a strong need for sustainable groundwater development and management planning to effectively manage and develop available resources to ensure freshwater supply as SDGs target 6.4 for the present and the future without making undesired impacts on the study area's environment. The findings of the present study provide an authentic assessment of the potential groundwater zones of the Betul-Chhindwara region, which can be used for planning sustainable development and management of groundwater resources. The results of this study will be helpful for government officials and decisionmakers in articulating an effective groundwater utilization plan in the study area.

\section{REFERENCES}

Aduah M.S. (2015). Analysis of Land Cover Change in Bonsa Catchment, Ankobra, Ghana. Appl. Ecol. Environ. Res.13:935-955

Banai R. (2010). Evaluation of land use - transportation systems with the analytic network process. Journal of Transport and Land Use, 3(1), 85-112.

CGWB (2009). A Report of Groundwater Resource Estimation Committee, Central Groundwater Board, Ministry of water resource, Government of India, 1-113

CGWB (2013). A Report of Groundwater Resource Estimation Committee, Central Groundwater Board, Ministry of water resource, Government of India, 1-135

Cheng E.W.L and Li H. (2004). Contractor selection using the analytic network process. Construction Management and Economics, 22, $1021-1032$.

Chowdhury A., Jha M. K., Chowdhary V. M. and Mal B. C. (2009). Integrated remote sensing and GIS-based approach for accessing groundwater potential in west Medinipur district, West Bengal, India. Int. J. Remote Sens, 30(1), 231-250.

Cook P.G., Walker G.R., Jolly I.D. (1989). Spatial variability of groundwater recharge in a semiarid region. Journal of Hydrology, 111 , 195-212

Dagdeviren M. and Ihsan Y. (2007). Personnel selection using analytic network process. Istanbul Ticaret Universitesi Fen BilimleriDergisiYil, 6(11), 99-118.

Das S. (2017). Delineation of groundwater potential zone in hard rock terrain in Gangajalghati block, Bankura district, India using remote sensing and GIS techniques. Modeling Earth Systems and Environ, 3(4), 1589-159.

Dehriya S. (2014). Development of Tribal Agriculture in Chhindwara-Seoni Region. Unpublished Ph.D. Thesis University of Sagar. 47-48.

District Groundwater Information Booklet (2013). Ministry of water resource, North Central Region, Bhopal India, 1-13.

Dunning D. J., Ross Q. E. and Merkhofer M. W. (2000). Multi attribute utility analysis for addressing Section 316(b) of the Clean Water Act. Environ Sci Policy, 3, 7-14.

Dwivedi C.S. (2007). Hydro-geomorphic study of sagar lake catchment area using remote sensing technique, Unpublished M.Phil. Dissertation University of Sagar. 28-32.

Dwivedi C.S., Husain J. and Shukla S. (2017). Change Detection Analysis Using Multi-Temporal Satellite Data: A Case study from Seoul and Gyeonggi-Do, South Korea. Forging a Multidimensional Partnership in the 21st Century, Manak Publication Pvt. Ltd. New Delhi. ISBN 978-93-7831-443-8

Fashae O. A., Tijani M. N., Talabi A. O. and Adedeji O. I. (2014). Delineation of groundwater potential zones in the crystalline basement terrain of SW-Nigeria: An integrated GIS and remote sensing approach. Applied Water Science ,4 (1), 19-38.

Flug M., Seitz H. L. H. and Scott J. F. (2000). Multi criteria decision analysis applied to Glen Canyon Dam. J. Water Resour Plan Manage, ASCE 126, 270-276. 
Galkate R., Thomas T., Pandey R.P., Singh S. and Jaiswal R.K. (2008). Assessment of rainwater availability and planning for water resources development in Chhindwara districtof MP, India. Journal of Indian Water Resources Society, 28(2), 6-14.

Ghosh P. K. Jana, N., C., (2017). Groundwater potentiality of the Kumari River Basin in drought prone Purulia upland, Eastern India: a combined approach using quantitative geomorphology and GIS. Sustainable Water Resources Management, 1-17.

Groundwater Year Book Madhya Pradesh (2016-17) CGWB, North Central Region, Ministry of Water Resource, River Development and Ganga Rejuvenation, Government of India, 1-142

Gupta M. and Srivastava P. K. (2010). Integrating GIS and remote sensing for identification of groundwater potential zones in the hilly terrain of Pavagarh, Gujarat, India. Water International, 35(2), 233-245.

Hajkowicz S. and Higgins A. (2008). A comparison of multiple criteria analysis techniques for water resource management. Eur J. Oper Res., 184, 255-265.

Jaiswal R., Mukherjee S., Krishnamurthy J. and Saxena R. (2003). Role of remote sensing and GIS techniques for generation of groundwater prospect zone towards rural development - an approach. Int. J. Remote Sens., 24(5), 993-108.

Jha M. K., Chowdary V. M. and Chowdhury A. (2010). Groundwater assessment in Salboni Block, West Bengal (India) using remote sensing, geographical information system and multi-criteria decision analysis techniques. Hydrogeology J, 18(7), 1713-1728.

Jhariya D. C., Kumar T., Gobinath M., Diwan P. and Kishore N. (2016). Assessment of groundwater potential zone using remote sensing, GIS, and multi criteria decision analysis techniques. J. Geol. Soc. India, 88(4), 481-492.

Joubert A., Stewart T. J. and Eberhard R. (2003). Evaluation of water supply augmentation and water demand management options for the City of Cape Town. J. Multi-Criteria Decis. Anal, 12, 17-25.

King L. C. (1962). The Morphology of the Earth, Edinburgh and London, Oliver and Boyd, (2),699.

Krishnamurthy J., Kumar N. V., Jayaraman V. and Manivel M. (1996). An approach to demarcate groundwater potential zone through remote sensing and a geographic information system. Int. J. Remote Sens., 17(10), 1867- 1884.

Leduc C., Favreau G., Schroeter P. (2001). Long-term rise in a Sahelian water-table: the continental terminal in south-west Niger. Journal of Hydrology, 243, 43-54.

Machiwal D., Jha M. K. and Mal B. C. (2011). Assessment of groundwater potential in a semi-arid region of India using remote sensing, GIS and MCDM techniques. J. Water Resourc. Manag, 25(5), 1359-1386.

Machiwal D., Rangi N. and Sharma A. (2015). Integrated knowledge- and data-driven approaches for groundwater potential zoning using GIS and multi-criteria decision-making techniques on hard-rock terrain of Ahar catchment, Rajasthan, India. Environ. Earth Sc., 73(4), 1871-1892.

Malczewski J. (1999) GIS and multi criteria decision analysis. New York: John Wiley and Sons, 392.

Malczewski J. (2006). GIS-based multi criteria decision analysis: A survey of the literature. Int. J. Geog. Info. Sc., 20(7), 703-726. Monitoring and Assessment, Kluwer Academic Publishers 94 263-277.

Malczewski J. and Rinner C. (2015). Multi criteria decision analysis in geographic information science. New York: Springer.

MOWR (2009). Report of the Groundwater Resource Estimation Committee. Ministry of Water Resources, Government of India, New Delhi, http://www.cgwb.gov.in.

Mukherjee P., Singh C. K. and Mukherjee S. (2012). Delineation of groundwater potential zones in arid region of India- A remote sensing and GIS approach. Water Resources Manag, 26(9), 2643-2672.

Murkute Y.A. and Joshi S.P. (2015). Environment of geological setting for uranium mineralization and geochemical exploration with review from central India. International Journal of Geology, Earth and Environmental Sciences, ISSN: 2277-2081, Vol. 5 (3) SeptemberDecember, 108-117

Guhathakurta P. and Rajeevan M. (2007). Trends in the rainfall pattern over Indi. International Journal of Climatology Int. J. Climatol. 28, 1453-1469, (2008) Published online 6 November 2007 in Wiley Inter Science (www.interscience.wiley.com) DOl: 10.1002/joc.1640

Pandey. A. and Dwivedi. C.S. (2014). Changing Land use Pattern in Ambedkarnagar District: A Block wise Analysis. National Geographer, Vol. XLIX, No.1+2, 97-108,

Phillips F.M. (1994). Environmental tracers for water movement in desert soils of the American Southwest. Soil Science Society of America Journal, 58, 14-24.

Rajeeva R., Rahul B., Shrivastava, V. K., Majumdar, A., Roy M. K. and Maithani P. B. (2012). Sedimentological and Geochemical Studies of Lower Gondwana Sediments in parts of Pench-Kanhan Sub-basin, Satpura Gondwana Basin, Chhindwara District, Madhya Pradesh: Implication for Uranium Mineralisation. Gond. Geol. Mag., 27(1), 1-16

Roark D.M., Healy D.F. (1998). Quantification of deep percolation from two flood-irrigated alfalfa fields, Roswell Basin, New Mexico. USGS Water Resources Investigation Report, 98-4096, 32.

Saaty T. L. (1980). The Analytic Hierarchy Process. McGraw- Hill, New York, NY.

Saaty T. L. (1996). Decision making with dependence and feedback, The Analytic Network Process. RWS Publications, Pittsburgh.

Saaty T. L. (1999). Fundamentals of the analytic network process. International Symposium of the Analytic Hierarchy Process (ISAHP), Kobe, Japan.

Saaty T. L. (2004). Fundamentals of the analytic network process - multiple networks with benefits, costs, opportunitie,s and risks. J. Systems Science and Systems Engineering, 13(3), 348-379.

Shankar M.N.R. and Mohan G. (2005). GIS based hydro-geomorphic approach foridentificationofsite-specificartificialrechargetechniquesinthe Deccan Volcanic Province. J Earth Sys Sci., 134(4), 505-514.

Shekhar S. and Pandey A. C. (2015). Delineation of groundwater potential zone in hard rock terrain of India using remote sensing, geographical information system (GIS) and analytic hierarchy process (AHP) techniques. Geocarto Int., 30(4), 402-421.

Shekhar S., Pandey A. C. and Tirkey A. S. (2014). A GIS-based DRASTIC model for assessing groundwater vulnerability in hard rock granitic aquifer. Arab J. Geosci, 8, 1385-1401.

Strahler, A.N. (1952). Hypsometric Analysis of Erosional Topography. Bull. Geol. Soc. Amer., 63, 1117-1142.

Sun H., Xu G. and Tian P. (2007). Design alternatives evaluation of emergency bridge by applying analytic network process (ANP). System Engineering Theory and Practice, 27(3), 63-70.

Tirkey A. S., Ghosh M. and Pandey A. C. (2016). Soil erosion assessment for developing suitable sites for artificial recharge of groundwater in drought prone region of Jharkhand state using geospatial techniques. Arab J Geosci,. 9, 362.

Tran L. T., Knight C. G., O'Neill R. V. and Smith E. R. (2004). Integrated environmental assessment of the Mid-Atlantic Region with Analytical Network Process. Environmental. 
Tyler S.W., Chapman J.B., Conrad S.H. (1996). Soil-water flux in the southern Great Basin, United States: temporal and spatial variations over the last 120,000 years. Water Resources Research, 32, 1481-1499

United Nations (2020). A Report "Sustainable Development Goals Report" Department of Economic and Social Affairs, 1-68, DOl: file:///E:/GES/The-Sustainable-Development-Goals-Report-2020.pdf

Wang Ru-Hang, Huang Jian-Guo and Zhang Qun-Fei (2009)“Underwater multiple target tracking decision making based on an analytic network process" Journal of Marine Science Application 8(4) 305-310.

Yang C. L., Chuang S. P., Huang R. H. and Tai C. C. (2008). Location selection based on AHP/ANP approach. IEEE, International Conference on Industrial Engineering and Engineering Management, Singapore, 1148-1153. 